\title{
Simulation of black carbon in snow and its climate impact in the Canadian Global Climate Model
}

\author{
M. Namazi ${ }^{1, a}$, K. von Salzen ${ }^{1}$, and J. N. S. Cole ${ }^{1}$ \\ ${ }^{1}$ Canadian Centre for Climate Modelling and Analysis, Environment Canada, Victoria, British Columbia, Canada \\ a now at: Department of Mathematics, University of Isfahan, Isfahan, Iran \\ Correspondence to: K. von Salzen (knut.vonsalzen@ec.gc.ca)
}

Received: 25 May 2015 - Published in Atmos. Chem. Phys. Discuss.: 9 July 2015

Revised: 15 September 2015 - Accepted: 18 September 2015 - Published: 30 September 2015

\begin{abstract}
A new physically based parameterisation of black carbon (BC) in snow was developed and implemented in the Canadian Atmospheric Global Climate Model (CanAM4.2). Simulated $\mathrm{BC}$ snow mixing ratios and $\mathrm{BC}$ snow radiative forcings are in good agreement with measurements and results from other models. Simulations with the improved model yield considerable trends in regional BC concentrations in snow and $\mathrm{BC}$ snow radiative forcings during the time period from 1950-1959 to 2000-2009. Increases in radiative forcings for Asia and decreases for Europe and North America are found to be associated with changes in $\mathrm{BC}$ emissions. Additional sensitivity simulations were performed in order to study the impact of BC emission changes between 1950 1959 and 2000-2009 on surface albedo, snow cover fraction, and surface air temperature. Results from these simulations indicate that impacts of $\mathrm{BC}$ emission changes on snow albedos between these 2 decades are small and not significant. Overall, changes in $\mathrm{BC}$ concentrations in snow have much smaller impacts on the cryosphere than the net warming surface air temperatures during the second half of the 20th century.
\end{abstract}

\section{Introduction}

Snow plays an important role in the land surface radiation budget and therefore climate. Snow albedo can be strongly reduced by absorbing aerosols such as black carbon (BC), brown organic carbon, or dust which have been deposited on the snow through dry and wet deposition and cause warming of the snowpack (Warren and Wiscombe, 1980,
1985; Hansen and Nazarenko, 2004; Hadley and Kirchstetter, 2012).

$\mathrm{BC}$ is produced by incomplete combustion of fossil and biomass fuels and is emitted into the atmosphere from a wide range of natural and anthropogenic sources. Total emissions of $\mathrm{BC}$ from fossil fuel and biofuel combustion have increased strongly from 1850 to 2000 (Bond et al., 2007; Skeie et al., 2011). In addition to effects on snow albedo, BC can affect Earth's climate through direct radiative, semi-direct, and indirect (cloud) effects.

An initial albedo reduction by $\mathrm{BC}$ in snow can be amplified by positive feedbacks involving snow processes, for example

- a warmer snowpack causes increases in snow grain effective radii (Flanner and Zender, 2006), which thereby causes further reductions in snow albedo;

- larger snow grain sizes in a warm snowpack leads to a stronger BC snow radiative forcing (Warren and Wiscombe, 1980; Hadley and Kirchstetter, 2012);

- BC tends to become more highly concentrated near the surface of the snowpack when snow melts (Clarke and Noone, 1985; Doherty et al., 2010); and

- an earlier snowmelt onset may cause an earlier exposure of a darker underlying surface.

Different models have been used to simulate impacts of BC on snow and climate. Hansen and Nazarenko (2004) used the few available measurements of BC in snow at that time to determine snow-albedo changes in the Arctic, Antarctica, Greenland, and other regions in the Northern Hemisphere. 
These albedo change estimates were used to calculate the radiative forcing (RF) and climate response. Jacobson (2004) estimated BC concentrations in snow prognostically and used them to calculate the change in albedo and RF. More recently, Flanner et al. (2007, 2009), Koch et al. (2009b), Rypdal et al. (2009), Skeie et al. (2011), and Jiao et al. (2014) used prognostic modelling methods to simulate $\mathrm{BC}$ in snow and interactions with climate.

Flanner et al. (2007) investigated impacts of BC in snow on snow radiative and microphysical processes. They performed simulations for strong and weak boreal fire years and suggested that both $\mathrm{BC}$ emissions and the treatment of snow aging represent large sources of uncertainty in the simulations of BC in snow. In a recent study of Jiao et al. (2014), BC deposition fields from 25 global aerosol models were used to investigate effects of $\mathrm{BC}$ transport and deposition processes on $\mathrm{BC}$ concentration in snow. The analysis reveals that these processes are more important for differences in simulated BC concentrations in snow than differences in snow meltwater scavenging rates or emissions in models.

Widespread surface melting of the Greenland ice sheet in 1889 and 2012 was recently attributed to warm temperatures combined with reductions in surface albedo resulting from deposition of $\mathrm{BC}$ from northern hemispheric forest fires (Keegan et al., 2014). However, the extent to which absorption of visible radiation by $\mathrm{BC}$ in snow might have contributed to rapid warming of the mid- to high-latitude land surface and decline in Eurasian springtime snow cover (Déry and Brown, 2007) is presently unknown. Studies of BC in snow are complicated by the fact that anthropogenic emissions of $\mathrm{BC}$ are non-uniform in space and time, compounded by large variations in atmospheric transport of $\mathrm{BC}$ at high latitudes (Stohl et al., 2006). In addition, there is large interannual variability in vegetation fire emissions of BC. Variations in total $\mathrm{BC}$ emissions are also compounded by changes in snow cover extent (SCE) and depth owing to variations in temperatures and snowfall. Consequently, concentrations of $\mathrm{BC}$ in snow are highly variable and climate effects are difficult to quantify robustly.

Some of the recent studies focused on RFs during individual years (Flanner et al., 2007, 2009) while Hansen et al. (2007a), Koch et al. (2009a, 2011), and Skeie et al. (2011) analysed differences between pre-industrial and present-day processes and climate. Some of the studies produced evidence for potentially large impacts of BC in snow on RFs and climate. For instance, Flanner et al. (2009) concluded that fossil fuel and biofuel emissions of $\mathrm{BC}$ induce a large springtime snow cover loss over Eurasia as a consequence of strong snow-albedo feedbacks and large BC emissions from Asia, with a magnitude similar to impacts of anthropogenic carbon dioxide concentrations on SCE. According to Koch et al. (2009a), BC in snow has caused an increase in surface air temperature between 1890 and 1995 that more than balances a decrease in surface air temperature caused by direct radiative effects of aerosols during this time period. How- ever, in a later study, Koch et al. (2011) found only small impacts of $\mathrm{BC}$ on snow and ice during the 20th century. In a related study, Holland et al. (2012) concluded that the deposition and cycling of aerosols in sea ice cause the sea ice to melt and may therefore play a role in late-20th-century Arctic sea ice trends. However, Goldenson et al. (2012) found that deposition of aerosols have small impacts on Arctic sea ice and climate.

The purpose of this work is to study impacts of BC emissions on cryospheric and climate processes in a recent version of the Canadian Atmospheric Global Climate Model (CanAM4.2). We apply a physically based parameterisation of the snow albedo in combination with new parameterisations for BC concentrations in snow and effective radii of snow grains, which are described in Sect. 2. Simulations of $\mathrm{BC}$ in snow, RFs of BC in snow, and changes in snow cover fraction (SCF) and surface air temperatures from 1950s to 2009s are discussed in Sect. 3.

\section{Modelling approach}

An interactive model treatment of $\mathrm{BC}$ emissions, transport, and deposition is required in order to simulate the RF of $\mathrm{BC}$ in snow and feedbacks between aerosol, snow physical processes, and climate. The CanAM4.2 is similar to the earlier version CanAM4 (von Salzen et al., 2013) but uses version 3.6 of the Canadian Land Surface Scheme (CLASS) to model the energy and water balances of the soil, snow, and vegetation canopy components (Verseghy, 2012). Relative to CanAM4, there are many improvements to the simulation of snow. These include new formulations for vegetation interception of snow (Bartlett et al., 2006), for unloading snow from vegetation (Hedstrom and Pomeroy, 1998), for the albedo of snow-covered canopies (Bartlett and Verseghy, 2015), for limiting snow density as a function of depth (Tabler et al., 1997; Brown et al., 2006), and finally for the thermal conductivity of snow (Sturm et al., 1997). Water retention in snowpacks has also been incorporated.

Other differences between CanAM4 and CanAM4.2 that are relevant to this study are the introduction of an aerosol microphysics scheme (von Salzen, 2006; Ma et al., 2008; Peng et al., 2012), a higher vertical resolution in the upper troposphere, a reduced solar constant $\left(1361 \mathrm{~W} \mathrm{~m}^{-2}\right)$, and an improved treatment of the solar continuum used in the radiative transfer. However, the model retains the same T63 spectral resolution, with 49 vertical levels.

Different types of natural and anthropogenic aerosols are considered, including sulfate, black and organic carbon, sea salt, and mineral dust. Parameterisations for emissions, transport, gas-phase and aqueous-phase chemistry, and dry and wet deposition account for interactions with simulated meteorological variables for each individual grid point and time step. Hydrophobic and hydrophilic black and organic carbon aerosol are considered with a specified lifetime, represent- 
ing aerosol aging processes of hydrophobic carbonaceous aerosols (Croft et al., 2005). Fluxes and properties of the air (downwelling long-wave and shortwave radiation, precipitation, air pressure and temperature, specific humidity, and wind speed) are passed to CLASS, which in turn computes the density, liquid water content, mass, and temperature of a single layer of snow at each time step. The snow-albedo calculation in CLASS explicitly accounts for neither snow metamorphism nor albedo reductions by $\mathrm{BC}$, which requires the addition of new parameterisations (Sect. 2.1).

\subsection{Radiative and snow microphysical processes}

A parameterisation for snow albedo which accounts for contributions of $\mathrm{BC}$ snow mixing ratio and the effective snow grain size was developed (Cole et al., 2015). For the sake of completeness the approach is described in brief. Lookup tables for snow albedo and transmission are used, which are functions of snow water equivalent, underlying surface albedo, solar zenith angle, snow grain size, and BC concentration. These tables are created for incident radiation that is purely direct beam or diffuse and for each radiation band in the CanAM4.2 radiative transfer model. Table contents are computed using the DISORT radiative transfer model (Stamnes et al., 1988). For each possible combination in the tables, DISORT calculations are performed for 280 different wavelengths between 0.25 and 4.0 microns, which are then averaged over each band, weighted by either incident direct or diffuse radiation. For each of the calculations, the optical properties of snow and $\mathrm{BC}$ are computed using Mie calculations. The size distribution and refractive indices for $\mathrm{BC}$ are taken to be that in Bäumer et al. (2007) to maintain consistency between the atmosphere and snow radiative effects.

The response of snow albedo to the presence of $\mathrm{BC}$, relative to pristine snow, is shown in Fig. 1 for a semi-infinite snow layer in which BC is externally mixed and illuminated by direct beam radiation at a $60^{\circ}$ zenith angle. For comparison, we show results from the Snow, Ice, and Aerosol Radiation (SNICAR) model (Flanner et al., 2007, 2009) using the same configuration. It is clear that the Cole et al. (2015) snow-albedo model produces an albedo response to $\mathrm{BC}$ in snow that is roughly $25 \%$ less than SNICAR for all $\mathrm{BC}$ concentrations and snow grain sizes. This can be largely attributed to the choice of BC optical properties. In SNICAR the mass absorption coefficient at $550 \mathrm{~nm}$ is $7.5 \mathrm{~m}^{2} \mathrm{~g}^{-1}$, following recommendations by Bond and Bergstrom (2006), while the parameterisation of Bäumer et al. (2007) produces a mass absorption coefficient of $4.9 \mathrm{~m}^{2} \mathrm{~g}^{-1}$ at $550 \mathrm{~nm}$. Recreating the lookup tables in Cole et al. (2015) with BC refractive indices that are consistent with SNICAR (Flanner et al., 2012) result in similar albedo responses due to $B C$ in snow in CanAM4.2 and SNICAR (not shown).

We consider snow over bare ground as well as on continental ice sheets and sea ice for the development of new parameterisations for snow grain sizes and $\mathrm{BC}$ concentra-

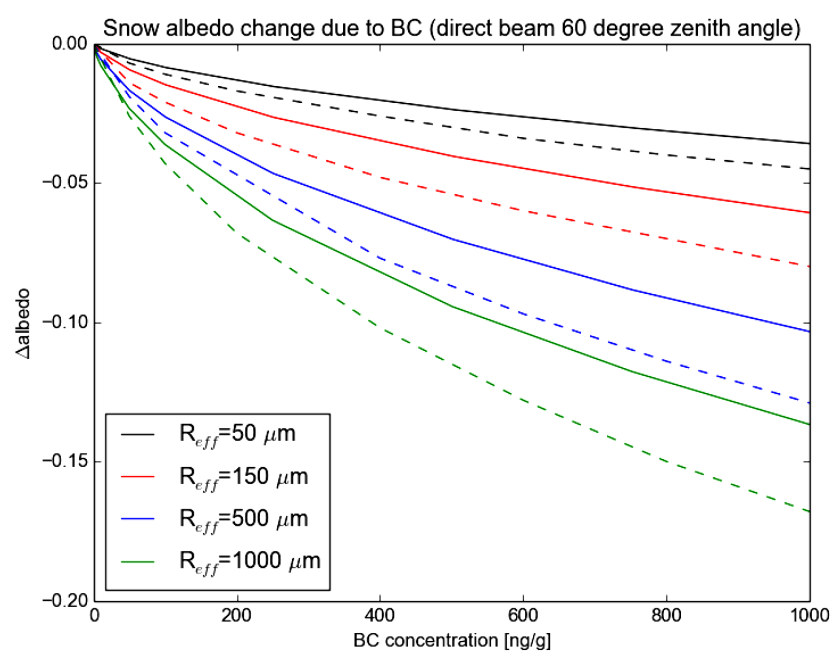

Figure 1. Response of snow albedo to the presence of $\mathrm{BC}$, relative to pristine snow, for different snow grain effective radii. Full lines refer to simulations based on the approach by Cole et al. (2015) in CanAM4.2; dashed lines refer to results from simulations with SNICAR (Flanner et al., 2007, 2009).

tions in snow. The existing parameterisations for snow in CLASS (3.6) are used to simulate properties of a single layer of snow with variable depth. Since vertical profiles of snow physical properties are not resolved in CLASS and extinction of solar radiation mainly occurs near the surface of snow layers, parameterisations of snow microphysical processes need to account for unresolved processes in the snowpack. The Snow Model Intercomparison Project (SnowMIP) experiments have shown that the performance of CLASS for simulations of the seasonal evolution of snow on land is comparable to that of a multi-layer snowpack model (Brown et al., 2006) despite the use of a single layer of snow.

\subsubsection{Snow metamorphism}

Snow grain size influences the snow albedo and thermal conductivity as well as chemical interaction between snow and atmosphere (Domine et al., 2008). It generally increases over time as the snowpack ages and therefore causes reductions in snow albedo, especially in the near infrared (Wiscombe and Warren, 1980). The visible albedo, however, depends more strongly on concentrations of snow impurities such as BC and mineral dust (Warren and Wiscombe, 1980). Larger snow grains amplify the rate of snow-albedo reduction by $\mathrm{BC}$ in snow (Hadley and Kirchstetter, 2012; Aoki et al., 2011). This is because of deeper radiation penetration in coarser snow grains (Warren and Wiscombe, 1980). In addition, the growth of snow grains contributes to snow-albedo feedbacks as the snowpack warms (Flanner and Zender, 2006). Therefore, an accurate model representation of snow grain sizes is potentially important for simulations of the effects of $\mathrm{BC}$ on climate. 
Snow with non-spherical complex particles can be represented as a collection of spheres, which conserves the volume-to-surface-area ratio well (the error is less than $5 \%$ ) (Grenfell and Warren, 1999; Grenfell et al., 2005). The effective radius, $R_{\mathrm{e}}$, the surface area-weighted mean radius of a collection of spherical particles, is given by

$R_{\mathrm{e}}=\frac{3}{\rho_{i} S}$,

where $\rho_{i}=917 \mathrm{~kg} \mathrm{~m}^{-3}$ is the bulk ice density. The snow specific surface area $(S)$ is defined as the ratio of the surface area per unit mass of snow in $\mathrm{m}^{2} \mathrm{~kg}^{-1}$, which defines atmosphere-snow chemistry interactions and surface energy balance through snow albedo and turbulent fluxes.

The size of the snow grains depends on the macrophysical state of the snowpack, which is determined by its temperature, type, density, and amount of liquid water. We consider three mechanisms for the temporal evolution of snow grain size in a layer at the top of the snowpack: dry aging, wet aging, and snow deposition. Other processes such as wind and sintering that can also affect snow grain size are not considered, owing to a lack of available parameterisations and simplicity of the CLASS snow model.

For dry aging of snow grains, we use a physically based approach by Flanner and Zender (2006) which predicts the temporal evolution of $R_{\mathrm{e}}(\mathrm{m})$, of dry snow due to water vapour transport in the snowpack, which is driven by differences in snow grain curvature and temperature gradient. The calculation depends on snowpack temperature, vertical temperature gradient, and snow density. It is formulated as

$\frac{\mathrm{d} R_{\mathrm{e}}}{\mathrm{d} t}=\left.\frac{\mathrm{d} R_{\mathrm{e}}}{\mathrm{d} t}\right|_{0}\left(\frac{\tau}{R_{\mathrm{e}}-R_{\mathrm{e}_{0}}+\tau}\right)^{\frac{1}{\kappa}}$,

where $\left.\frac{\mathrm{d} R_{\mathrm{e}}}{\mathrm{d} t}\right|_{0}\left(\mathrm{~m} \mathrm{~s}^{-1}\right)$ is the initial rate of change of the effective radius, and $\tau$ and $\kappa$ are empirical parameters which account for the spatial distribution of grain sizes and irregularity in grain spacing and are specified according to the original version of the parameterisation. $R_{\mathrm{e}_{0}}$ is the effective radius of fresh snow and is set to $54.53 \mu \mathrm{m}$, corresponding to $\mathrm{SSA}_{0}=60 \mathrm{~m}^{2} \mathrm{~kg}^{-1}$ (Flanner et al., 2007) based on observational data of Legagneux et al. (2004).

The parameterisation of wet aging accounts for the increase in snow grain size by rounding due to the presence of liquid water within the snowpack. This process is modelled using an empirical equation expressed in terms of $R_{\mathrm{e}}$ $(\mu \mathrm{m})$,

$\frac{\mathrm{d} R_{\mathrm{e}}}{\mathrm{d} t}=\frac{10^{18} C_{1} f_{\mathrm{liq}}{ }^{3}}{4 \pi R_{\mathrm{e}}^{2}}$,

based on experimental data (Brun, 1989; Oleson et al., 2010). Here $C_{1}=4.22 \times 10^{-13}$ and $f_{\text {liq }}$ is the mass liquid water fraction given by $\frac{W_{\text {liq }}}{W_{\text {liq }}+W_{\text {ice }}}$, where $W_{\text {liq }}$ and $W_{\text {ice }}$ are the masses of water and ice $\left(\mathrm{kg} \mathrm{m}^{-2}\right)$ respectively. Flanner et al. (2007) also use this parameterisation for wet aging.

We parameterise the effects of snowfall on mean snow effective radii in a shallow layer at the surface of the snowpack according to

$\frac{\mathrm{d} R_{\mathrm{e}}}{\mathrm{d} t}=-\frac{1}{\tau_{d}}\left(R_{\mathrm{e}}-R_{\mathrm{e}_{0}}\right)$,

where $\tau_{d}$ is an adjustment time scale which is given by

$\tau_{d}=\frac{\rho_{\mathrm{s}} z_{\mathrm{s}}}{F_{\mathrm{s}}}$

for $F_{\mathrm{s}}>0$. Here, $z_{\mathrm{s}}(\mathrm{m}), \rho_{\mathrm{S}}\left(\mathrm{kg} \mathrm{m}^{-3}\right)$ and $F_{\mathrm{S}}\left(\mathrm{kg} \mathrm{m}^{-2} \mathrm{~s}^{-1}\right)$ are instantaneous snow depth, density of snow layer, and snowfall flux respectively. If there is no snowfall $\left(F_{\mathrm{s}}=0\right)$ then the effective radius remains constant. We use $z_{\mathrm{s}}=25 \mathrm{~cm}$ as the maximum depth of the surface snow layer in parameterisations of snow grain size, corresponding to a typical depth of solar penetration in snow (France et al., 2011). If the depth of snowpack is shallower than $5 \mathrm{~cm}$, the effective radius is kept constant. We found a weak sensitivity of results to the assumed depth of the snow layer between 15 and $25 \mathrm{~cm}$, which does not affect the conclusions presented in the following.

There are few field measurements for the effective radius of snow with vertical profiles available which can be used to validate parameterisations for snow grain sizes. The measurements which we use are from six locations and are summarised in Table 1 . The averaged simulated effective radius corresponding to the location and month of the measurements is $0.29 \pm 0.18 \mathrm{~mm}$. This is comparable to an averaged observed effective radius of $0.22 \pm 0.11 \mathrm{~mm}$.

\subsubsection{BC concentration in snow}

The parameterisation of $\mathrm{BC}$ concentrations in snow is based on a BC mass budget for a shallow homogeneous layer of snow at the top of the snowpack, with the additional simplifying assumption that there is no transfer of $\mathrm{BC}$ between the layer and underlying snow except for removal of $\mathrm{BC}$ by meltwater scavenging. The $\mathrm{BC}$ concentration is determined by accumulation rates of $\mathrm{BC}$ and snow through deposition processes. In addition, partial scavenging of $\mathrm{BC}$ by melting snow water will act to increase the $\mathrm{BC}$ concentration in the top layer. Processes such as the advection of $\mathrm{BC}$ and snow by wind or sea ice and effects of sublimation of snow on BC concentrations are not considered.

The parameterisation has the following components.

- $\mathrm{BC}$ deposition: the $\mathrm{BC}$ concentration $\left(\mathrm{kg} \mathrm{m}^{-3}\right)$ in the snow layer increases by $\mathrm{BC}$ deposition and decreases by snowfall. If changes in snow density are omitted and the layer depth $\left(z_{\mathrm{s}}\right)$ is constant, then

$$
\frac{\mathrm{d} C}{\mathrm{~d} t}=\frac{F_{\mathrm{b}}}{z_{\mathrm{s}}}-\frac{C F_{\mathrm{s}}}{\rho_{\mathrm{s}} z_{\mathrm{s}}},
$$


Table 1. Observed and simulated effective radii of snow in surface snow.

\begin{tabular}{llccl}
\hline Region & Sampling period & Mean obs. (mm) & Mean model (mm) & Reference \\
\hline $\begin{array}{l}\text { Fairbanks, Alaska } \\
\left(64.87^{\circ} \mathrm{N}, 147.73^{\circ} \mathrm{W}\right)\end{array}$ & Nov 2003 to Apr 2004 & 0.36 & 0.42 & Taillandier et al. (2006) \\
$\begin{array}{l}\text { Dome } \mathrm{C}, \text { Antarctic plateau } \\
\left(75.1^{\circ} \mathrm{S}, 123.33^{\circ} \mathrm{E}\right)\end{array}$ & Nov 2008 to Jan 2009 & 0.15 & 0.23 & Gallet et al. (2012) \\
$\begin{array}{l}\text { Barrow, Alaska } \\
\left(71.33^{\circ} \mathrm{N}, 203.34^{\circ} \mathrm{E}\right)\end{array}$ & Mar 2009 to Apr 2009 & 0.13 & 0.58 & Domine et al. (2012) \\
$\begin{array}{l}\text { Col de Porte, France } \\
\left(45.30^{\circ} \mathrm{N}, 5.77^{\circ} \mathrm{E}\right)\end{array}$ & Sep 2009 to May 20 & 0.32 & 0.11 & Morin et al. (2013) \\
$\begin{array}{l}\text { Churchill, Canada } \\
\left(58.74^{\circ} \mathrm{N}, 66.18^{\circ} \mathrm{E}\right)\end{array}$ & Jan 2010 to Apr 2010 & 0.23 & 0.18 & Derksen et al. (2012) \\
$\begin{array}{l}\text { Montmorency, Canada } \\
\left(47.33^{\circ} \mathrm{N}, 288.87^{\circ} \mathrm{E}\right)\end{array}$ & Jan 2012 to Mar 2012 & 0.10 & 0.19 & Unpublished data by F. Domine \\
\hline
\end{tabular}

where $F_{\mathrm{b}}$ is the total BC deposition flux $\left(\mathrm{kg} \mathrm{m}^{-2} \mathrm{~s}^{-1}\right)$, resulting from dry deposition and convective and largescale wet deposition.

The BC snow mass budget can also be expressed as an adjustment of the concentration towards an effective surface BC concentration:

$\frac{\mathrm{d} C}{\mathrm{~d} t}=-\frac{1}{\tau_{d}}\left(C-C_{0}\right)$,

where the adjustment time scale $\left(\tau_{d}\right)$ is given by Eq. (5). The effective surface concentration $\left(C_{0}\right)$ is given by $C_{0}=\rho_{\mathrm{s}} \frac{F_{\mathrm{b}}}{F_{\mathrm{s}}}$. If there is no snowfall, then the change in $\mathrm{BC}$ concentration is given by $\lim _{F_{\mathrm{s}} \rightarrow 0} \frac{\mathrm{d} C}{\mathrm{~d} t}=\frac{F_{\mathrm{b}}}{z_{\mathrm{s}}}$.

- Scavenging: Snow meltwater can scavenge hydrophilic $\mathrm{BC}$ out of the snow layer. However, BC may accumulate near the surface during the melt as observed in Conway et al. (1996), Xu et al. (2006), and Doherty et al. (2010) and enhance the RF due to incomplete scavenging (Flanner et al., 2007). We parameterised this process by assuming the $\mathrm{BC}$ concentration change in time to be proportional to the meltwater flux and concentration of $\mathrm{BC}$ in the snow surface layer:

$\frac{\mathrm{d} C}{\mathrm{~d} t}=(1-s) \frac{F_{\mathrm{w}}}{\rho_{\mathrm{s}} z_{\mathrm{s}}} C$.

Here, $F_{\mathrm{w}}\left(\mathrm{kg} \mathrm{m}^{-2} \mathrm{~s}^{-1}\right)$ is the meltwater flux out of the snow layer and $0 \leq s \leq 1$ is the scavenging factor. For $s=1$, in case of a perfectly efficient scavenging efficiency, the concentration of $\mathrm{BC}$ on top of the snow layer is not changed by the melting of snow. In the other limiting case of $s=0$, BC is not removed by snow meltwater and therefore tends to accumulate in the snow surface layer over time. We choose $s=0.1$ for which the simulated BC are in good agreement with measured BC (Doherty et al., 2010). Rypdal et al. (2009) and Skeie et al. (2011) assume that all BC remains at the snow surface as snow melts while Flanner et al. (2007, 2009) and Jiao et al. (2014) apply a scavenging efficiency of 0.2 for hydrophilic BC and 0.03 for hydrophobic BC, based on Conway et al. (1996). In contrast, Hansen et al. (2005) and Koch et al. (2009b) did not include any contribution of snowmelt to BC snow concentrations.

\subsection{Simulation set-up}

In order to investigate $\mathrm{BC}$ in snow and effects on cryospheric and climate processes, two simulations were performed from 1950 to 2009 with 1 year of model spin-up for 1949 . In the control simulation (CTRL), snow aging and BC concentration in the snow are calculated prognostically using the parameterisations described in the previous sections. A sensitivity experiment (EXP) based on CTRL is performed by applying specified monthly climatological BC concentrations in snow rather than time-varying prognostic values. The climatological BC concentrations in this simulation were obtained by temporal averaging of $\mathrm{BC}$ concentration in snow over the first decade of the control simulation, 1950-1959, for times when snow is present. Consequently, differences between the two simulations can be attributed to differences in simulated $\mathrm{BC}$ RF in snow evolving over time relative to the 1950 s.

Simulations were performed following specifications outlined by Taylor et al. (2011). Monthly mean sea surface temperature (SST) and sea-ice boundary conditions were used for the model lower boundary (Hurrell et al., 2008). These are the same boundary condition data that were required for the fifth Coupled Model Intercomparison Project (CMIP5). Time-varying monthly averaged concentrations for $\mathrm{CO}_{2}, \mathrm{CH}_{4}, \mathrm{O}_{3}, \mathrm{~N}_{2} \mathrm{O}$, effective $\mathrm{CFC} 11$, and CFC12 were those of the historical period used in the CMIP5 project and extended to 2010 using the Representative Concentration Pathway (RCP4.5) scenario (Moss et al., 2010).

Emissions of BC and other aerosol compounds were provided using a combination of linearly interpolated monthly 
emission fluxes from different data sets in an attempt to include the most recent improvements in newly available emission data sets. Anthropogenic emissions in 2005 and subsequent years were specified according to the Evaluating the Climate and Air Quality Impacts of Short-Lived Pollutants (ECLIPSE) inventory, version 4a (Klimont et al., 2015a, b; Stohl et al., 2015). Monthly varying emissions for forest and grass fires from GFED, version 3.1, were used for 1997 and subsequent years (van der Werf et al., 2010). Aircraft and shipping emissions and emissions before the first year of these data sets were taken from the CMIP5/RCP data base (Lamarque, 2010; Moss et al., 2010), with linear interpolation of the data sets in time between available start and end years.

With this approach, total global mean emissions of BC in CanAM4.2 are 4.87 Tgyear $^{-1}$ during 1950-1959 and $8.82 \mathrm{Tg}$ year $^{-1}$ during 2000-2009. The latter agrees well with the CMIP5/RCP data emissions during this time period (available at http://tntcat.iiasa.ac.at:8787/RcpDb/dsd? Action $=\mathrm{htmlpage} \&$ page $=$ compare $)$. However, differences in regional emission patterns exist owing to improved temporal resolution, the addition of new emission sectors, and other revisions in the updated data set.

By using the observation-based SSTs and sea ice extent according to the CMIP5 approach, simulated climate conditions and $\mathrm{BC}$ concentrations are directly comparable to observations. However, this implies that feedbacks between BC in snow, oceanic heat transport, and sea ice are not accounted for in the simulations. Implications of this approach will be discussed in detail in the following.

Ensemble mean results are used to account for natural atmospheric variability in the simulations. We performed simulations with eight ensemble members for each of the control and experiment simulations. Note that ocean and sea ice conditions are identical for each ensemble member. This implies that differences in ensemble mean results will represent only the portion of variability of the natural climate system which is associated with variations in atmospheric and land surface processes, disregarding ocean and sea ice processes.

\subsection{Simulated and observed BC in snow and ice}

\subsubsection{Deposition of $\mathrm{BC}$}

To simulate the $\mathrm{BC}$ concentration in snow accurately, we require accurate BC deposition fluxes. Simulated BC deposition fluxes were compared to ice-core measurements at four locations in Greenland (McConnell et al., 2007, 2010; McConnell and Edwards, 2008) during the time period of the simulations. The ice cores were collected in 2003 in Greenland at Act2 $\left(66.00^{\circ} \mathrm{N}, 45.2^{\circ} \mathrm{W}\right), \mathrm{D} 4$ $\left(71.4^{\circ} \mathrm{N}, 43.9^{\circ} \mathrm{W}\right)$, Humboldt $\left(78.5^{\circ} \mathrm{N}, 56.8^{\circ} \mathrm{W}\right)$, and Summit $\left(72.6^{\circ} \mathrm{N}, 38.3^{\circ} \mathrm{W}\right)$. BC contents in the ice cores were measured with a laser soot photometer (SP2) and were used to derive the deposition flux of $\mathrm{BC}$ from 1772 to 2003. An- nually averaged $\mathrm{BC}$ deposition fluxes from these measurements and CanAM4.2 are shown in Fig. 2. CanAM4.2 reproduces the declining trend in the observed $\mathrm{BC}$ deposition flux for Greenland, which may be explained by a decrease in emissions and transport of BC from North America. The model results are in particularly good agreement with measurements at Summit and D4. However, the model underestimates deposition rates at the south-westerly locations and the trends are also weaker compared to the measurements. Note that the observed interannual variability is particularly large for these two sites which is likely associated with local processes either in the atmosphere or in the snow and ice. Moreover, model results are much less variable at these locations.

\subsubsection{BC snow mixing ratio}

Extensive data sets of observed $\mathrm{BC}$ mass mixing ratios in snow have very recently become available for model validation. Doherty et al. (2010) provides the first large survey of $\mathrm{BC}$ snow mass mixing ratios in eight different regions in the Arctic: (1) Arctic Ocean, (2) Canadian Arctic, (3) Alaska, (4) Canadian subarctic, (5) Greenland, (6) NyÅlesund, (7) Tromsø, and (8) Russia in 1998 and 2005-2009. In Wang et al. (2013), 400 snow samples were gathered at 46 sites across northern China in January and February 2010. Finally, a recent field campaign was conducted that included 67 North American sites in 13 American states and 3 Canadian provinces (Doherty et al., 2014). For all of these studies, vertical profiles of light-absorbing particles in snow in different vertical intervals throughout the snowpack are available. The spectrally resolved total light absorption of samples was analysed and used to estimate snow $\mathrm{BC}$ mass mixing ratios and their contribution to the total absorption by $\mathrm{BC}$ and nonBC particles.

In Fig. 3, we compare simulated annual mean BC mass mixing ratios in snow with annual mean measurements from the new observational data sets for corresponding grid cells and months. Since simulated results are representative of the top $25 \mathrm{~cm}$ of the snowpack, we vertically averaged the available measured profiles for each location using given interval depths as weights. If multiple measurements were taken on different days in a specific month of a year, we average the measurements over that month. Results from only one model ensemble member are shown. Results from other ensemble members are similar.

As shown in Fig. 3, CanAM4.2 broadly reproduces observed large-scale patterns of high concentrations in China and low concentrations for Greenland. Observations and model results are generally in good agreement, especially for sites in the Canadian Arctic, Canadian subarctic, and Alaska. However, CanAM4.2 systematically underestimates concentrations for Chinese sites. For Russia, observed high concentrations of $\mathrm{BC}$ in snow of more than $100 \mathrm{ng} \mathrm{g}^{-1}$ at sites near Tiksi on the Arctic Ocean coast are not reproduced by 

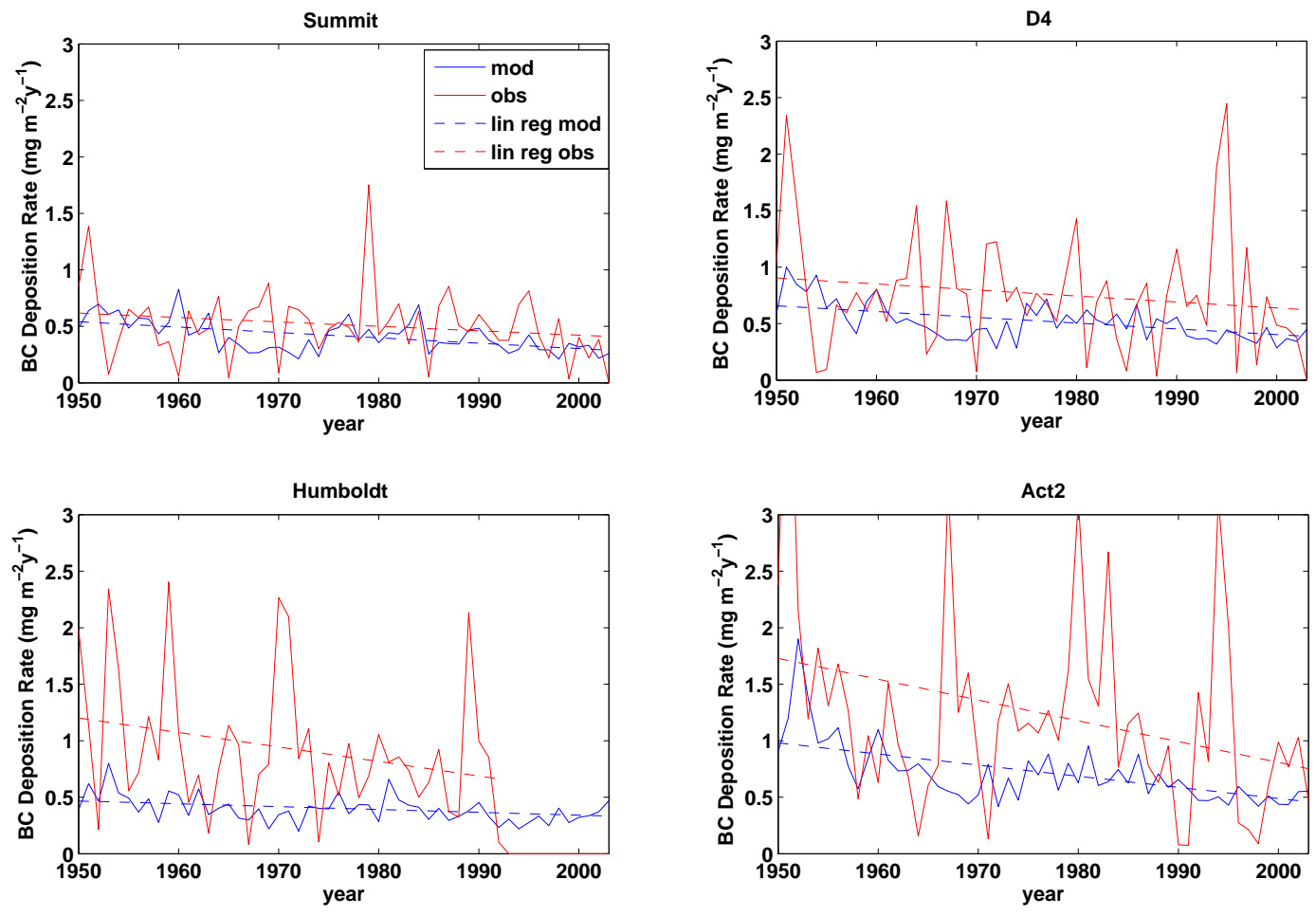

Figure 2. Measured and modelled black carbon (BC) deposition flux in ice cores in Greenland at Summit (72.6 $\left.{ }^{\circ} \mathrm{N}, 38.3^{\circ} \mathrm{W}\right)$ (top left), D4 $\left(71.4^{\circ} \mathrm{N}, 43.9^{\circ} \mathrm{W}\right)$ (top right), Humboldt $\left(78.5^{\circ} \mathrm{N}, 56.8^{\circ} \mathrm{W}\right)$ (bottom left), and Act2 $\left(66.0^{\circ} \mathrm{N}, 45.2^{\circ} \mathrm{W}\right)$ (bottom right) from 1950 to 2009. The measurements (solid line) and their linear regression (dashed line) are in red and the model results (solid line) and their linear regression (dashed line) are in blue.

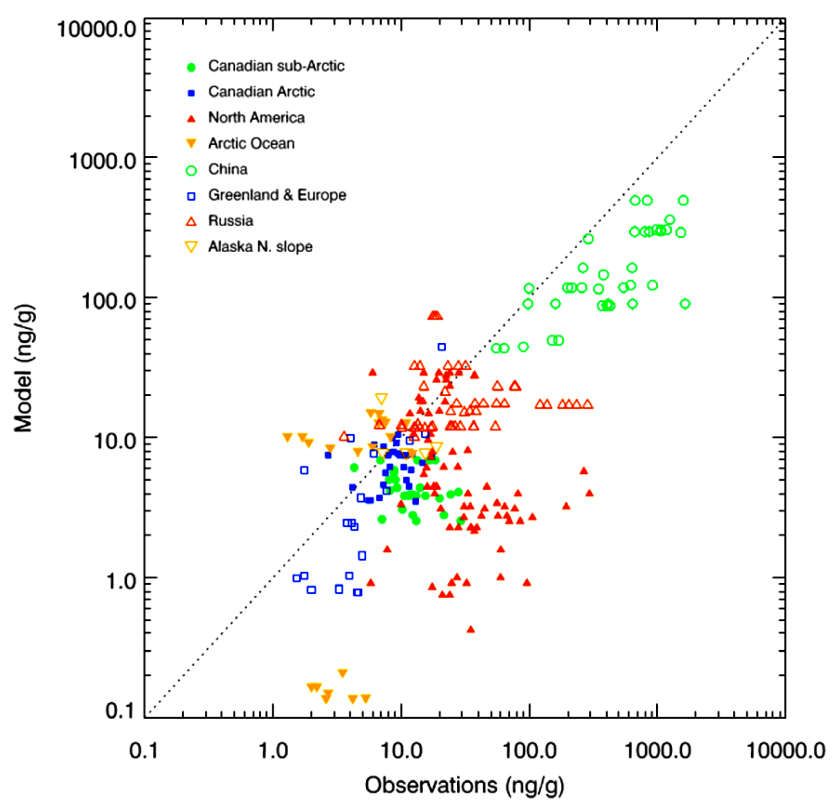

Figure 3. Comparison of measured and modelled BC in snow in log-scale scatter plot. The measurements are vertically averaged over depth for the top $25 \mathrm{~cm}$ and compared to simulated results over the same grid box and month. the model, which can likely be attributed to local BC emissions in this region that are not accounted for in the emission data set. Concentrations of $\mathrm{BC}$ in North America are well reproduced at latitudes above about $50^{\circ} \mathrm{N}$ and systematically underestimated at lower latitudes. The mean simulated and measured BC snow concentrations averaged over all samples temporally and spatially are 35 and $108 \mathrm{ng} \mathrm{g}^{-1}$ respectively, and the correlation between model results and observations is 0.84. Note that biases for Chinese sites contribute significantly to the differences in sample mean concentrations, which incompletely reflect conditions in the Northern Hemisphere. Despite the unprecedented size of the observational data set employed here, a rigorous validation of $\mathrm{BC}$ concentrations in snow in global models will require measurements over longer time periods and from additional regions. Note that the large variability in simulated $\mathrm{BC}$ concentrations in snow over Arctic Ocean sea ice compared to observation in Fig. 3 can likely be attributed to differences in BC mass budgets in snow over sea ice. This may be related to the omission of advection of sea ice and other processes for snow on sea ice in the model.

Biases in simulated $\mathrm{BC}$ snow concentrations are partly related to emissions. Models generally tend to substantially underestimate absorption aerosol optical depth for North American and Asian sites, which has been attributed to a lack of 

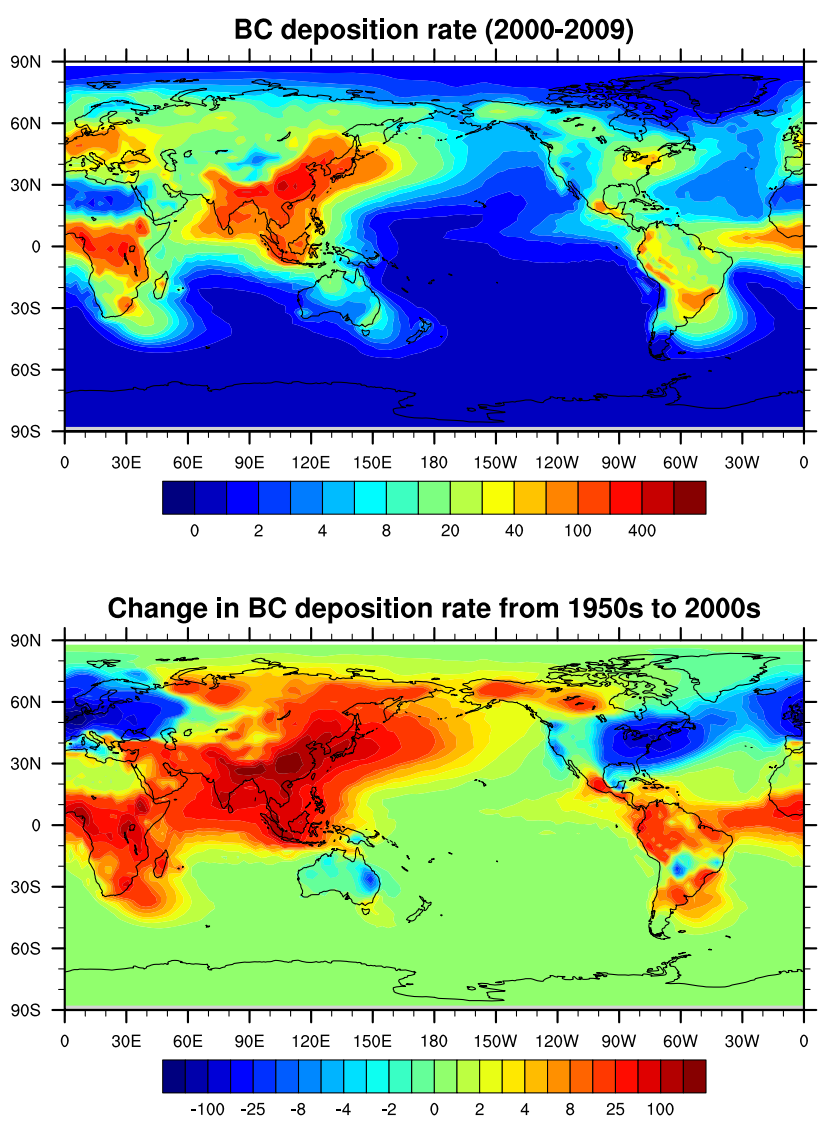

Figure 4. Annual mean $\mathrm{BC}$ deposition flux $\left(\mathrm{mg} \mathrm{m}^{-2} \mathrm{yr}^{-1}\right)$ during 2000-2009 (top) and annual mean BC deposition flux change from the 1950 s to 2000 s (bottom).

BC emissions in these regions (Koch et al., 2009b; Bond et al., 2013). This is broadly consistent with underestimates of absorption aerosol optical depth and near-surface atmospheric concentrations of BC in CanAM4.2 in these regions (not shown). Similarly, Kopacz et al. (2011) found that BC concentrations in snow were underestimated in their simulations at Chinese sites. However, there are no obvious systematic regional biases in $\mathrm{BC}$ concentration in snow in the Arctic in models (Bond et al., 2013). Koch et al. (2009a) and Skeie et al. (2011) extended their comparison to include measurements from Forsström et al. (2009) as well.

\section{Change in $\mathrm{BC}$ in snow and snow-climate processes between 1950-1959 and 2000-2009}

The following analysis of $\mathrm{BC}$ in snow and impacts on the cryosphere and climate will focus on the period 2000-2009. Changes since 1950-1959 will also be analysed. Global anthropogenic BC emissions from fossil and biofuel sources have steadily increased by $73 \%$ from 1950 to 2000 (Lamarque, 2010). This corresponds to about half of the total increase in global anthropogenic BC emissions since 1850.
The mean simulated deposition of BC for 2000-2009 is shown in the top panel of Fig. 4. CanAM4.2 produces local maxima in the deposition flux near the equator due to the proximity of vegetation fire sources and efficient atmospheric BC removal by wet deposition in precipitating cloud systems. Other notable deposition maxima in the Northern Hemisphere are related to emissions from Asia and Europe. A minimum in $\mathrm{BC}$ deposition occurs for Greenland, which can be largely attributed to the relatively high elevation of the topography. Simulated BC concentrations in air tend to decrease strongly with altitude in CanAM4.2 in the Arctic which leads to a decreasing efficiency of dry and wet deposition processes with elevation.

Corresponding to increases in global $\mathrm{BC}$ emissions, the mean BC deposition flux has increased from 1950-1959 to 2000-2009 with particularly large increases for East and Southeast Asia in Fig. 4. Decreases for North America and Europe reflect reductions in emissions from air quality regulatory activities and technology improvements in these regions. For instance, decreases in amounts of carbonaceous aerosol have been documented based on ice-core measurements in Europe since the 1970s (Legrand et al., 2007) and air sampling across the United States during 1990-2004 (Murphy et al., 2011). However, BC emission from China and the rest of Asia has increased substantially over the last 4 decades, which largely explains increases in $\mathrm{BC}$ deposition for Asia and the North Pacific. It is estimated that BC emissions from China have increased $30 \%$ from 2000 to 2005 and 21 and $41 \%$ from China and India respectively between 1996 and 2010 (Lei et al., 2011; Lu et al., 2011). BC deposition over Greenland is mostly affected by North American emissions, except during winter. Consequently, simulated trends in $\mathrm{BC}$ deposition for Greenland are consistent with trends in emissions from North America. Emissions from Europe and East Asia play a more important role for BC deposition elsewhere in the Arctic (Shindell et al., 2008).

The annual mean BC concentration in snow during 20002009 in Fig. 5 is spatially well correlated with the BC deposition flux in Fig. 4, with high BC concentrations in snow in Europe, Russia, China, and South and East Asia. In the Arctic, Greenland has the cleanest snow, consistent with low deposition rates. Similar patterns are simulated during the spring season (March-April-May, MAM), which is a particularly important time period for RFs of climate by BC in snow given the high SCE and solar insolation in the Northern Hemisphere during this time of the year. Similarly, changes in the concentration of $\mathrm{BC}$ in snow and $\mathrm{BC}$ deposition fluxes from the 1950s to the 2000s agree well with each other. Large increases in $\mathrm{BC}$ deposition fluxes for the Tibetan Plateau and the Himalayas lead to equivalent increases in $\mathrm{BC}$ concentrations in snow in these regions, with only relatively small differences between annual mean and MAM. The simulated reduction in $\mathrm{BC}$ concentrations in snow in Europe, North America, and Greenland agrees with the declining trends in deposition rates for these regions in Fig. 4. 

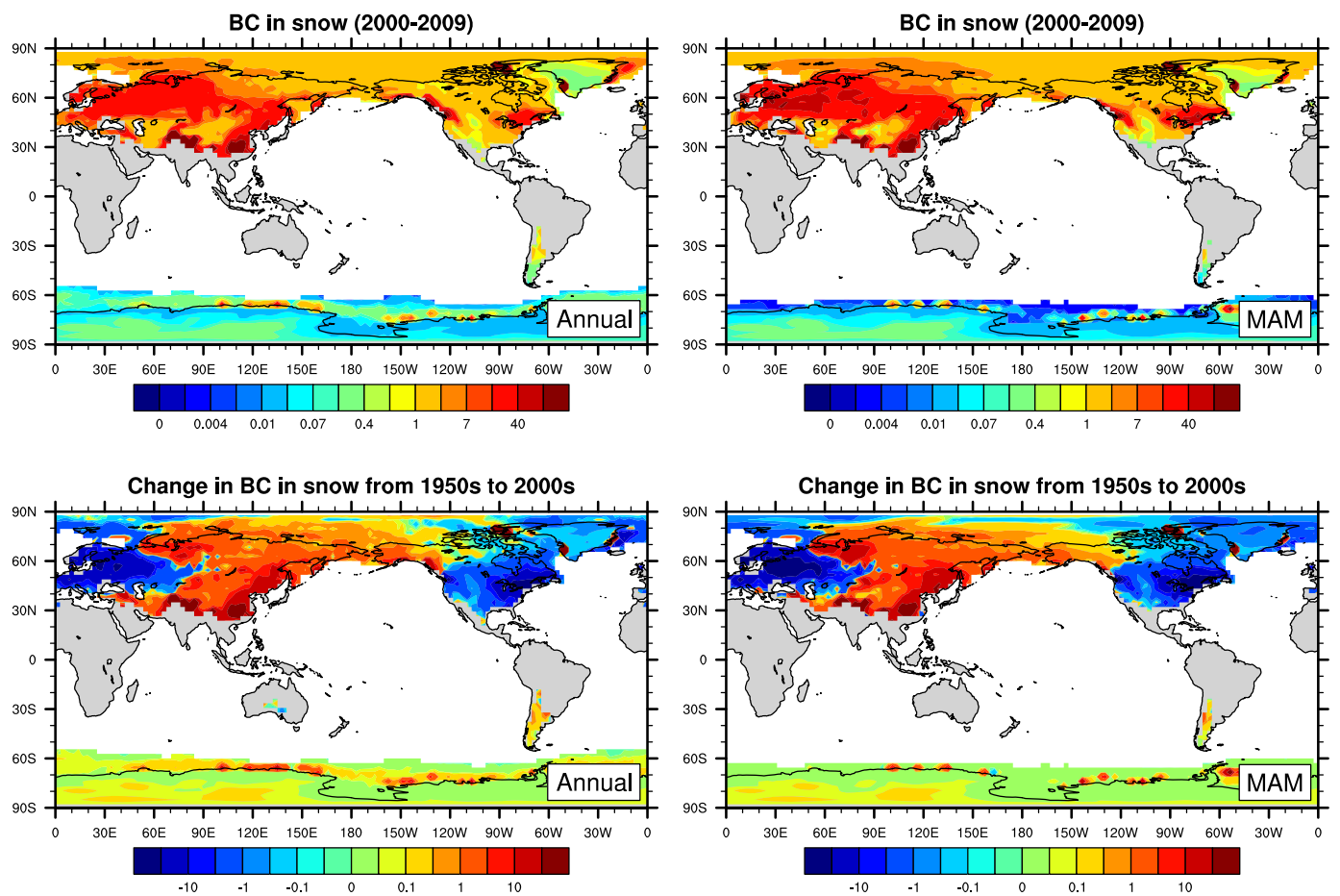

Figure 5. Annual mean (top left) and spring mean (top right) BC concentration in snow ( $\mathrm{mg} \mathrm{m}^{-3}$ ) during 2000-2009 and annual mean (bottom left) and spring mean (bottom right) change in BC concentration in snow $\left(\mathrm{mg} \mathrm{m}^{-3}\right.$ ) from the 1950s to $2000 \mathrm{~s}$.

\subsection{Radiative forcing}

The instantaneous $\mathrm{RF}$ of $\mathrm{BC}$ in snow (BC present - no BC present) for 2000-2009 and the change in RF due to changes in BC concentrations in snow between 1950-1959 and 20002009 are shown in Fig. 6. Changes that are significant at $95 \%$ confidence level according to a Student $t$ test are hatched, based on a model ensemble of eight members (bottom panels). The changes in RF agree broadly with changes in BC in snow shown in Fig. 5 with stronger (weaker) RF change for higher (lower) concentrations. However, the relationship between BC concentrations and RF depends on solar insolation, snow grain size, snow depth, and other factors, which cause the RF to vary spatially and temporally. The global mean simulated RF for 2000-2009 is $0.045 \mathrm{~W} \mathrm{~m}^{-2}$ (annual) and $0.080 \mathrm{~W} \mathrm{~m}^{-2}$ (MAM). The mean RF in the Arctic north of $60^{\circ} \mathrm{N}$ is $0.140 \mathrm{~W} \mathrm{~m}^{-2}$ (annual) and $0.317 \mathrm{~W} \mathrm{~m}^{-2}$ (MAM).

Increases in global mean BC concentrations in snow between 1950-1959 and 2000-2009 lead to increases in global $\mathrm{RF}$ of $0.011 \mathrm{~W} \mathrm{~m}^{-2}$ (annual) and $0.008 \mathrm{~W} \mathrm{~m}^{-2}$ (MAM). The mean change in RF in the Arctic is 0.003 for (annual) and $-0.004 \mathrm{~W} \mathrm{~m}^{-2}$ (MAM). Statistically significant RF reductions for Europe, North America, and Greenland are consistent with reductions in $\mathrm{BC}$ concentrations in snow in these regions and are in contrast to an increase in RF for large portions of Asia, especially in MAM. Increases in RF are most pronounced for the Himalayas and Tibetan Plateau because of high $\mathrm{BC}$ deposition fluxes and long persistence of SCE into the year in these regions. Given the large magnitude of the RF, an intensification of glacial snowmelt in these regions by BC in snow as observed in Lau et al. (2010) and modelled in Flanner et al. (2009) seems plausible. However, the horizontal resolution of CanAM4.2 is insufficient for a more detailed analysis of forcing changes and processes in these regions.

In comparison, other studies estimate present-day global mean RF of BC in snow from all BC sources to be between +0.01 and $+0.08 \mathrm{~W} \mathrm{~m}^{-2}$ (Flanner et al., 2007, 2009; Hansen et al., 2007a; Koch et al., 2009a; Rypdal et al., 2009; Skeie et al., 2011; Wang et al., 2011; Lee et al., 2013b), with a best estimate of $0.04 \mathrm{Wm}^{-2}$ in Bond et al. (2013), which agrees well with our results $\left(0.045 \mathrm{~W} \mathrm{~m}^{-2}\right)$. In a study of the Aerosol Comparisons between Observations and Models (AeroCom) project (Jiao et al., 2014) a range of Arctic RF from 0.06 to $0.28 \mathrm{~W} \mathrm{~m}^{-2}$ was reported. Note that different $\mathrm{BC}$ emission inventories are used in different studies and results also often refer to different years. In addition to the $\mathrm{BC}$ in snow, some models also account for BC in sea ice. Moreover, differences in diagnostic calculations of RF also exist. All these factors contribute to differences in RF estimates.

The efficacy of BC in snow, the change in global mean equilibrium temperature per unit of $\mathrm{RF}$ relative to the temperature response to $\mathrm{CO}_{2} \mathrm{RF}$, is on the order of 3, with individual estimates ranging from 2.7 (Hansen et al., 2007b) to 3.17 (Flanner et al., 2007). This relatively large impact of $\mathrm{BC}$ in snow on global temperatures results from efficient 

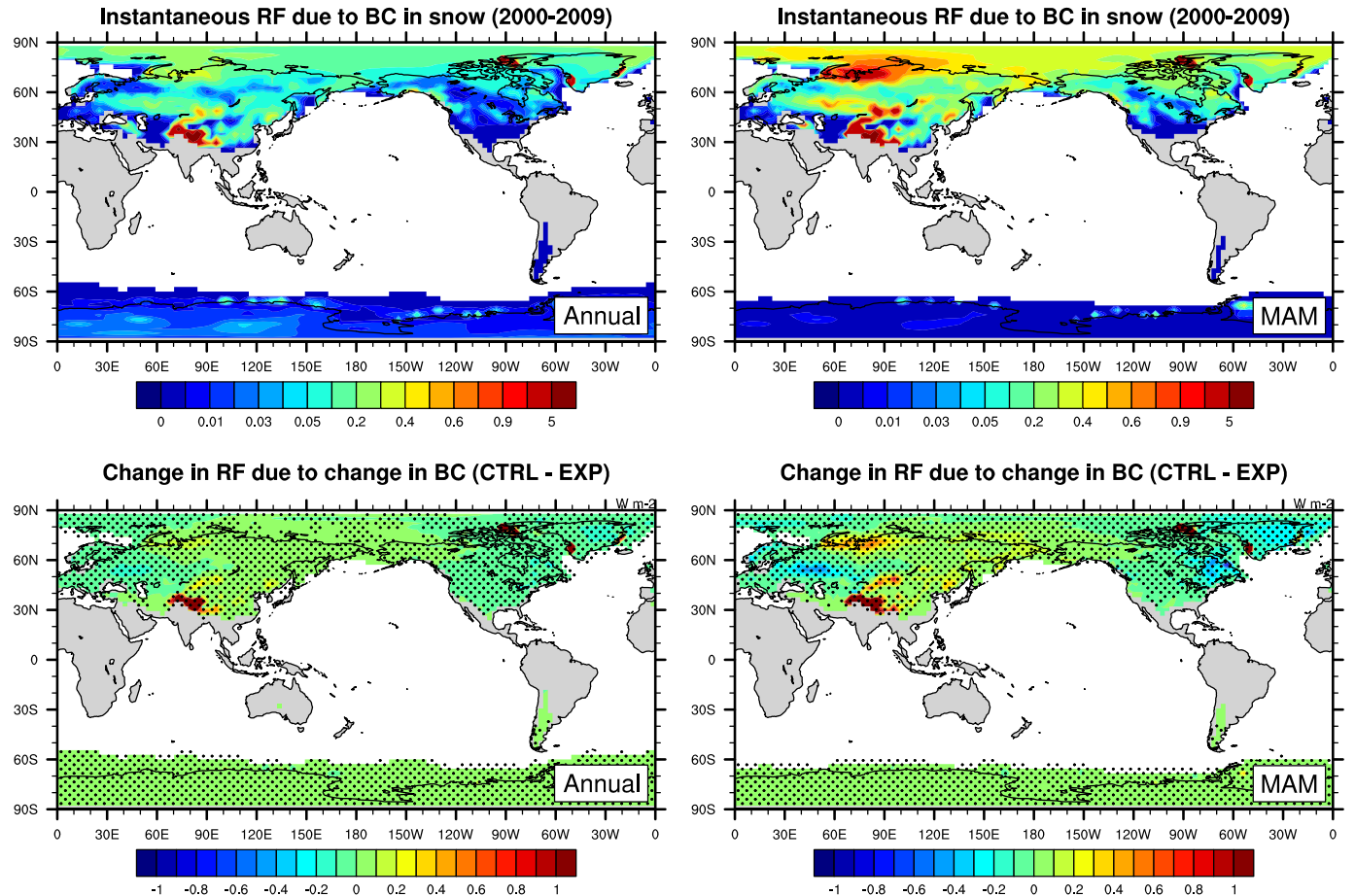

Figure 6. Annual mean (top left) and spring mean (top right) all-sky instantaneous radiative forcing of $\mathrm{BC}$ in snow (W m ${ }^{-2}$ ) during $2000-$ 2009 and annual mean (bottom left) and spring mean (bottom right) radiative forcing changes $\left(\mathrm{W} \mathrm{m}^{-2}\right.$ ) due to $\mathrm{BC}$ in snow from the $1950 \mathrm{~s}$ to 2000 s. Hatching indicates regions where the results are statistically significant $(p=0.05)$.

snow-albedo feedbacks (Sect. 1). Based on an efficacy of BC in snow of 3 and an equilibrium climate sensitivity of $3.37^{\circ} \mathrm{C}$ (Andrews et al., 2012), our estimate of global mean RF of $\mathrm{BC}$ in snow implies a global mean equilibrium temperature response of $0.03^{\circ} \mathrm{C}$ from changes in $\mathrm{BC}$ in snow between 1950-1959 and 2000-2009. Note that this estimate accounts for responses of SSTs and sea ice feedbacks to RF of BC in snow.

\subsection{Impacts of $\mathrm{BC}$ in snow on cryosphere and climate}

In an analysis strategy similar to the previous sections, the impacts of changes of $\mathrm{BC}$ concentrations in snow between 1950-1959 and 2000-2009 on the cryosphere will be investigated. Recall that climatological mean $\mathrm{BC}$ in snow from the 1950s replaces the actual BC in snow in the EXP simulation.

The middle panel of Fig. 7 shows the effect of the change in BC snow concentrations between 1950-1959 and 20002009 on shortwave broadband surface albedos. Note that surface albedo is calculated from reflected and absorbed radiative fluxes at the surface. Although physically coherent and statistically significant changes in RF of BC in snow were found (Fig. 6), changes in surface albedo are weak and not statistically significant. There is a strong reduction near the Himalayas and Tibetan Plateau which is associated with increasing BC deposition over time in these areas. Local patterns in albedo changes generally do not agree well with changes in RF of $\mathrm{BC}$ in snow. The weak response of surface albedos to BC RF in snow in Fig. 7 can be attributed to variations in snow processes in the simulations which arise from natural variations in amount and properties of snow in the Northern Hemisphere that are associated with precipitation and temperature (Brown and Robinson, 2011). Owing to large simulated variations in snow properties, impacts of $\mathrm{BC}$ in snow on surface albedo are very small and negligible for almost all regions. This is also apparent from results of individual ensemble members (not shown). Therefore, the results generally give no indication of large positive feedbacks of snow albedo to BC in snow, with the notable exception of the region comprising the Himalayas and Tibetan Plateau.

In comparison, total net changes in surface albedos between 1950-1959 and 2000-2009 in the control simulation with changes in greenhouse gas RF included are substantial (Fig. 7, bottom panel). Significant reductions in sea ice fraction and SCF over Europe and Northern Asia lead to significant reductions in surface albedos, as will be further discussed in the following. There is no obvious relationship between changes in surface albedo and $\mathrm{BC}$ in snow for most of the regions. However, for the Himalayas and Tibetan Plateau, the changes in surface albedos are similar to changes in surface albedos induced by $\mathrm{BC}$ in snow. This indicates that cryospheric changes in these regions during the time period of the simulation may have been substantially affected by 

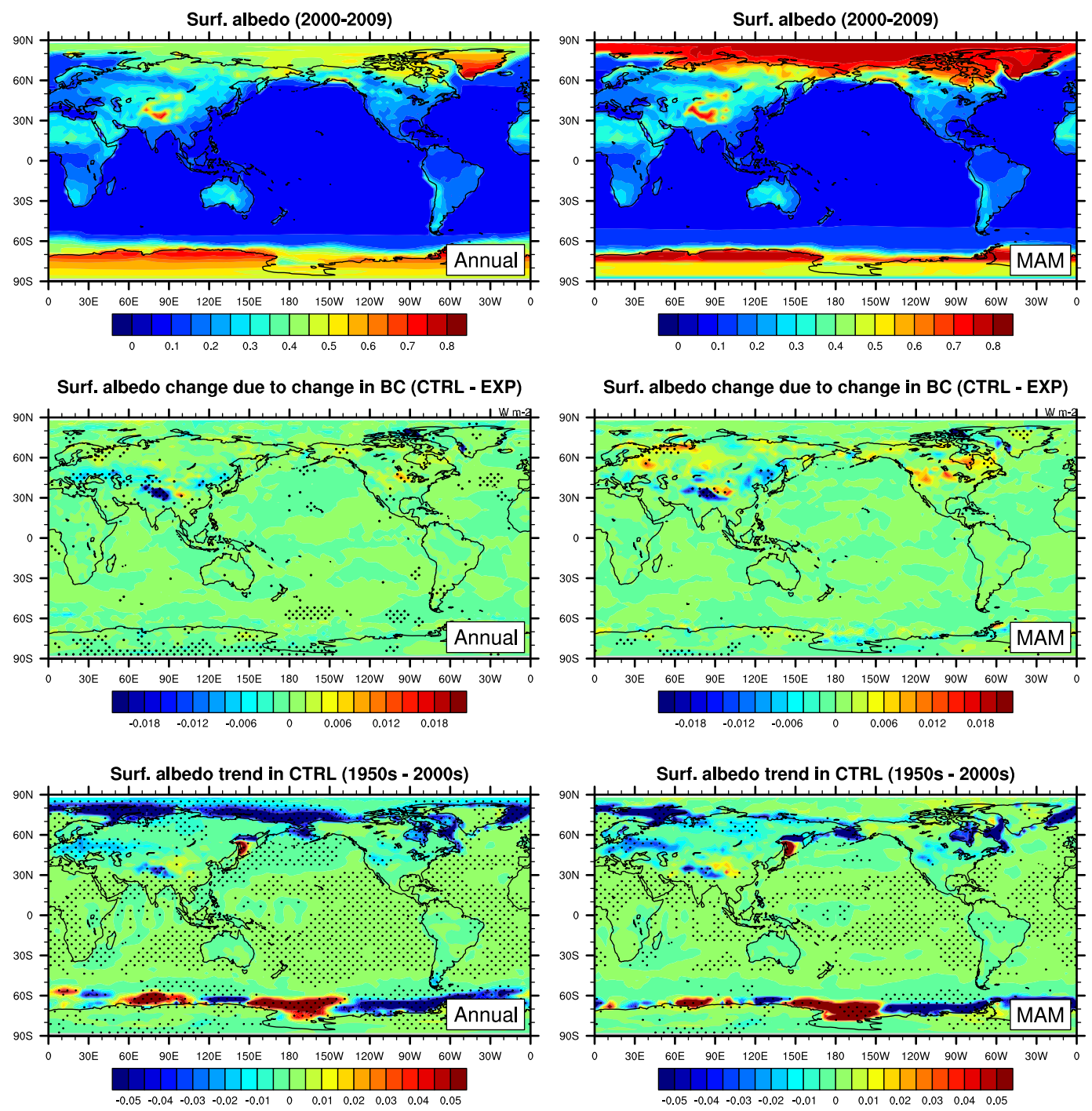

Figure 7. Annual mean (top left) and spring mean (top right) surface albedo during 2000-2009, annual mean (middle left) and spring mean (middle right) surface albedo changes due to BC in snow from the 1950s to 2000s, and annual mean (bottom left) and spring mean (bottom right) surface albedo changes due to all forcing from the 1950s to 2000s. Hatching indicates regions where the results are statistically significant $(p=0.05)$.

changes in $\mathrm{BC}$ in snow. However, confidence in these results is low given the low resolution of the model.

Although impacts of changes in $\mathrm{BC}$ in snow on surface albedos are not statistically significant and therefore unlikely to affect local climate processes systematically, we analysed changes in SCF and surface air temperature for consistency and completeness.

As expected, there are no statistically robust changes in annual SCF that are associated with changes of BC in snow (Fig. 8, middle panel). Reductions of SCF in Eurasia and increases of SCF in North America appear to be broadly consistent with $\mathrm{BC}$ emissions increase in Eurasia and reduction in North America but they are not statistically significant. However, the simulated increase in SCF in northern Russia is counter-intuitive because $\mathrm{BC}$ concentration has increased from the 1950s to 2000s. The reductions in SCF in the Himalayas and Tibetan Plateau are consistent with an accumulation of $\mathrm{BC}$ in snow in these regions. In comparison, significant reductions in SCF in the control run between the 1950s and 2000s in the Northern Hemisphere, especially near the boundaries of the Arctic ocean, Eurasia, and Northern Asia, can be largely attributed to the specified reductions in sea ice fraction and increasing SSTs between these decades (Fig. 8, bottom panel). These results are broadly consistent with observations in Déry and Brown (2007) which show that SCF in Eurasia and North America during spring 1979-2008 has decreased by 13.5 and $6 \%$ respectively since $1968-1978$. 

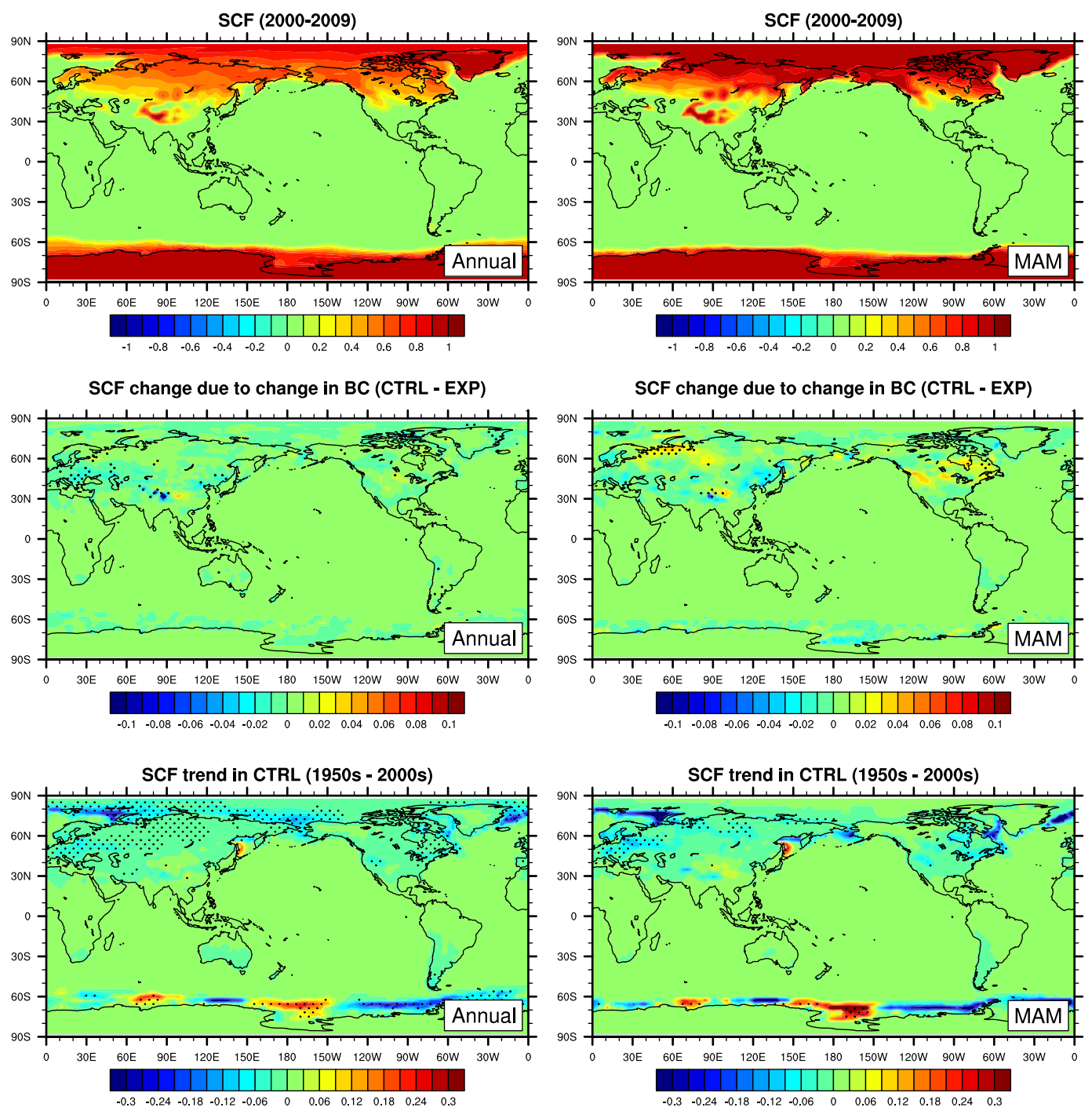

Figure 8. Annual mean (top left) and spring mean (top right) snow cover fraction during 2000-2009, annual mean (middle left) and spring mean (middle right) snow cover fraction changes due to BC in snow from the 1950s to 2000s, and annual mean (bottom left) and spring mean (bottom right) snow cover fraction changes due to all forcing from the 1950s to 2000s. Hatching indicates regions where the results are statistically significant $(p=0.05)$.

Our results appear to contradict conclusions by Flanner et al. (2009), according to which emissions of BC induce a large springtime snow cover loss over Eurasia. This is despite a similar global RF of $0.054 \mathrm{~W} \mathrm{~m}^{-2}$ (1998) and $0.049 \mathrm{~W} \mathrm{~m}^{-2}$ (2001) and emissions of $8.80 \mathrm{Tg}$ year $^{-1}$ (1998) and 6.70 $\mathrm{Tg}_{\text {year }}{ }^{-1}$ (2001) (Flanner et al., 2007). The differences between this and our study can at least be partly attributed to the fact that the earlier study addressed total impacts of all present-day $\mathrm{BC}$ emissions, whereas we focus on impacts of emission changes from the 1950s to 2000s here. For instance, present-day emissions from vegetation fires are large and have only slightly increased since pre-industrial times (Lamarque, 2010) and therefore produce only minor contributions to changes in $\mathrm{BC}$ in snow since the end of the 19th century. In another study, Koch et al. (2009a) attributed a reduction in snow and ice cover extent of $1.2 \%$ in the Arctic from 1890 to 1995 to RF by BC in snow based on equilibrium simulations with an atmospheric model coupled to a slab ocean model. However, in a more recent study of transient climate change with a fully coupled climate model, Koch et al. (2011) concluded that the darkening of snow albedos by $\mathrm{BC}$ has not caused recent snow cover and sea ice extent Arctic losses, with simulated changes in global (Arctic) snow cover and sea ice extent of $-0.06 \%(-0.26 \%)$ and $0.02 \%(0.33 \%)$ from the 1890 s to $1990 \mathrm{~s}$ and 1970 s to 1990s respectively. They argued that fully coupled transient simulation produces smaller aerosol impacts on climate by 

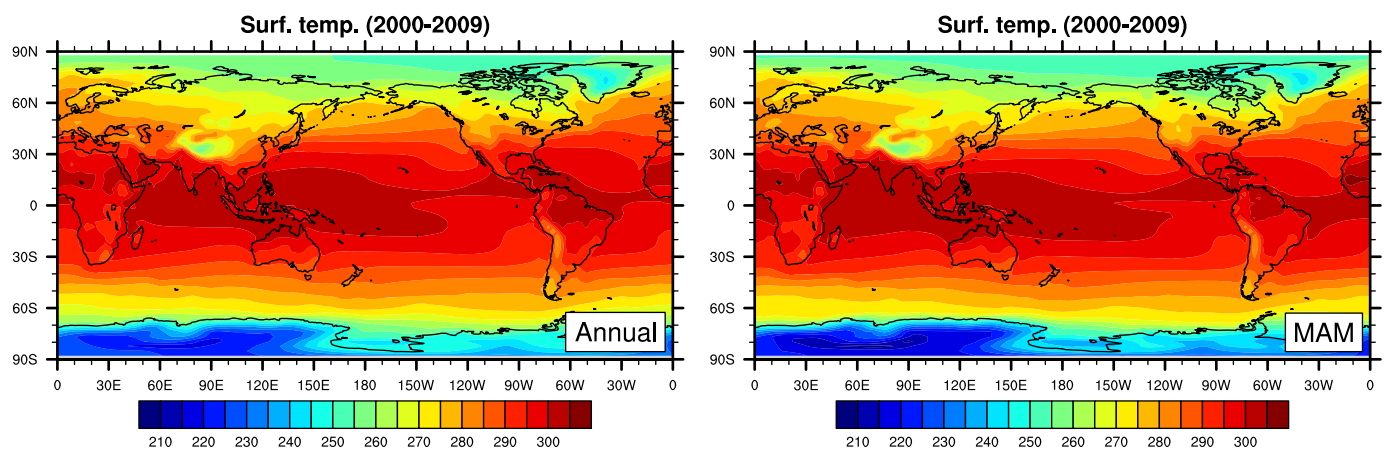

Surf. temp. change due to change in BC (CTRL - EXP)

Surf. temp. change due to change in BC (CTRL - EXP)
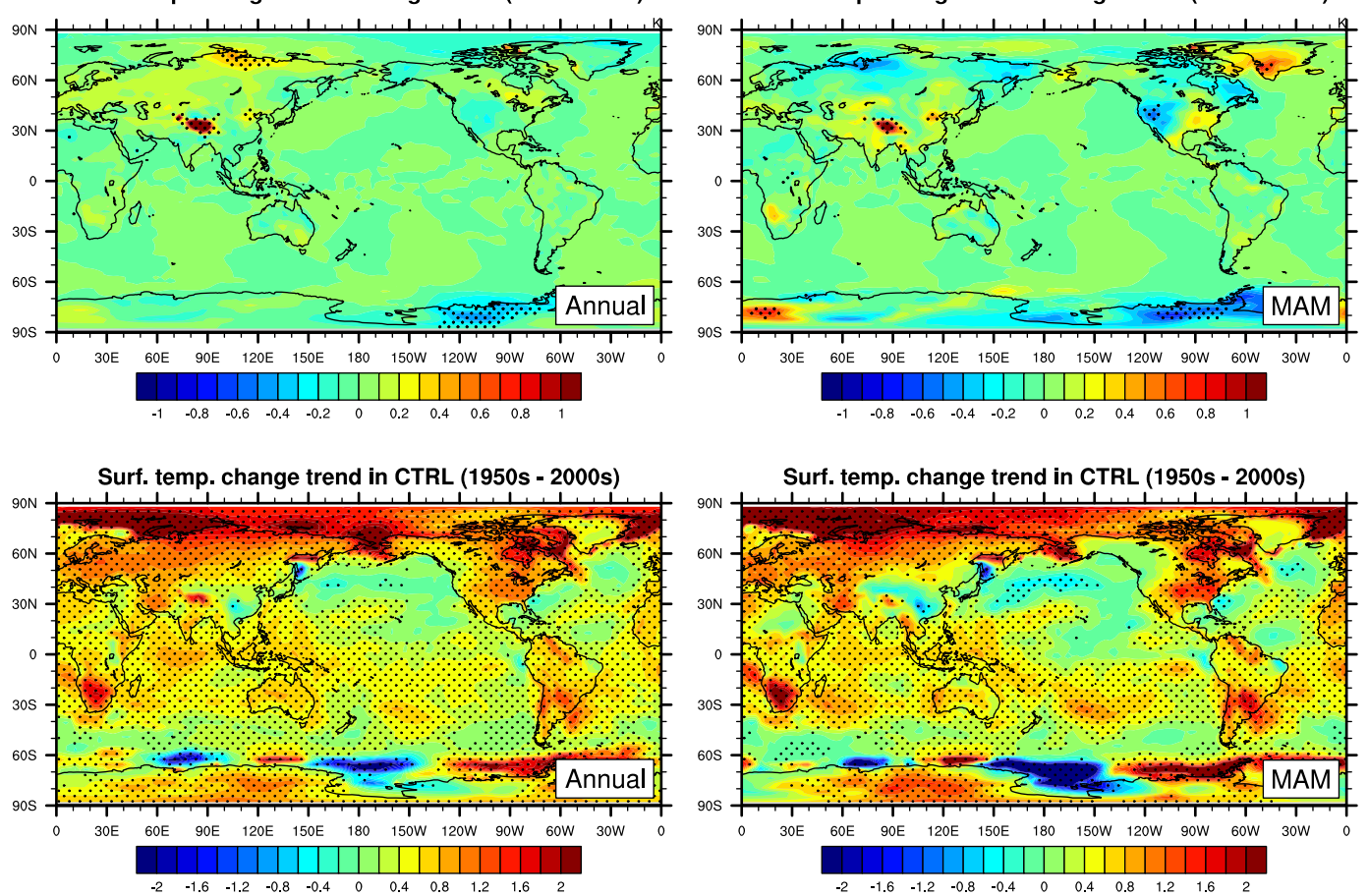

Figure 9. Annual mean (top left) and spring mean (top right) near-surface air temperature (K) during 2000-2009, annual mean (middle left) and spring mean (middle right) near-surface air temperature changes (K) due to BC in snow from the 1950s to 2000s, and annual mean (bottom left) and spring mean (bottom right) near-surface air temperature changes (K) due to all forcing from the 1950s to 2000s. Hatching indicates regions where the results are statistically significant $(p=0.05)$.

accounting for moderating effects of ocean heat uptake on simulated temperature changes.

Changes in $\mathrm{BC}$ in snow are not generally associated with any statistically robust changes in surface air temperature in CanAM4.2 (Fig. 9). Locally, the warming is considerable for the Himalayas and Tibetan Plateau, consistent with BC snow concentration and albedo changes in these regions.

In contrast, significant warming is simulated in the control run with all greenhouse gas and aerosol RFs in large portions of the Northern Hemisphere between 1950-1959 and 2000-2009. The increase in simulated Arctic (global) mean surface air temperature is $1.41(0.63)^{\circ} \mathrm{C}$ for annual and $1.46(0.60){ }^{\circ} \mathrm{C}$ for MAM. However, recall that all-forcing changes in Fig. 9 also account for changes in SSTs and sea ice whereas effects of $\mathrm{BC}$ in snow were evaluated using specified SSTs and sea ice during 2000-2009 (Sect. 2.2). Consequently, increases in SSTs owing to positive RF of BC in snow are omitted for the latter, although they are likely to be very small (Sect. 3.1).

Similar to results for SCF discussed earlier, our simulated changes in near-surface air temperature do not agree with warming trends due to $\mathrm{BC}$ in snow according to Flanner et al. (2007, 2009) and Koch et al. (2009a). The simulated Arctic (global) ensemble mean temperature response to $\mathrm{BC}$ in snow in our simulations is $-0.007(-0.001)^{\circ} \mathrm{C}$ in the annual mean and $-0.027(-0.019)^{\circ} \mathrm{C}$ for MAM. This yields a temperature change per unit of emission flux close to $0^{\circ} \mathrm{C} \mathrm{yr} \mathrm{Tg}^{-1}$. In comparison, the Arctic (global) annual mean equilibrium 
temperature response from total $\mathrm{BC}$ in snow was estimated as $1.61(0.15)$ and $0.50(0.10)^{\circ} \mathrm{C}$ for 1998 and 2001 respectively (Flanner et al., 2007, 2009), corresponding to a global mean temperature change per unit of emission flux of 0.015$0.017^{\circ} \mathrm{C} \mathrm{yr} \mathrm{Tg}^{-1}$. According to Koch et al. (2009a), BC in snow has caused an increase in temperature of $0.5(0.2)^{\circ} \mathrm{C}$ in the Arctic (global) over the 20th century based on equilibrium climate simulations. However, Koch et al. (2011) simulated transient Arctic (global) temperature changes of $\mathrm{BC}$ in snow of $+0.20(-0.03)^{\circ} \mathrm{C}$ and $-0.17(-0.02)^{\circ} \mathrm{C}$ for the 1890s-1990s and 1970s-1990s respectively. Clearly, the magnitude of the simulated temperatures response depends on the choice of time period and associated changes in emissions in these studies. Temperature responses to changes in $\mathrm{BC}$ in snow are affected by substantial variability in climate and are poorly constrained in models.

The net impact of changes in concentrations of $\mathrm{BC}$ in snow on snow albedos depends on the magnitude of snow-albedo feedbacks, which determine how strongly surface warming is amplified through a reduction in surface albedo resulting from warming or melting snow (Qu and Hall, 2007). Fletcher et al. (2015) showed that climate models generally reproduce observation-based estimates of snow-albedo feedbacks well but tend to underestimate the temperature sensitive component of the total snow-albedo feedback. This implies that where snow persists, its albedo does not reduce fast enough when the temperature warms, including warming from absorption of solar radiation by BC in snow. A very recent and preliminary analysis shows that the version of the model configuration used here produces a net snow-albedo feedback that is about $20 \%$ weaker than observed, which can likely be attributed to a weak response of the temperature sensitive component of the total snow-albedo feedback (C. G. Fletcher, personal communication, 2015). This could potentially lead to a relatively weak response of surface albedos to changes in $\mathrm{BC}$ in snow in the simulations presented here. Impacts of BC in snow on snow albedo in CanAM4.2 have not yet been compared to results from other models and observations. It is therefore unclear how realistic impacts of $\mathrm{BC}$ in snow on snow albedos in CanAM4.2 are.

\section{Conclusions}

The effect of black carbon (BC) in CanAM4.2 was investigated. The modelling approach accounts for snow metamorphism and $\mathrm{BC}$ concentration in snow, which affect snow albedo. We validated our models by comparing the estimated $\mathrm{BC}$ deposition and $\mathrm{BC}$ mixing ratio against extensive field measurements, which produced good agreement. We estimated annual global and Arctic mean radiative forcings (RFs) of BC in snow during 2000-2009 of 0.04 and $0.14 \mathrm{~W} \mathrm{~m}^{-2}$ respectively within the range reported by previous studies. Although the RF due to $\mathrm{BC}$ in snow is locally large and comparable to other studies, changes in $\mathrm{BC}$ concentrations in snow between the 1950s and 2000s generally do not lead to any statistically significant changes in surface albedo, snow cover fraction, and surface air temperature based on simulations using eight ensemble members. Furthermore, we demonstrate that the simulated changes are much weaker than changes caused by greenhouse gas and other aerosol RFs during these decades.

Results from our study do not agree with results from some of the earlier studies which indicated large impacts of total $\mathrm{BC}$ in snow on snow cover extent and surface air temperature. This may be partly related to differences in magnitudes of transient and equilibrium climate responses to $\mathrm{BC}$ in snow, which cannot be assessed without additional simulations with coupled atmosphere/ocean models. In addition, differences in snow-albedo feedbacks in models potentially contribute to differences in responses in climate to changes in $\mathrm{BC}$ concentrations in snow. Consequently, more rigorous model comparisons with focus on snow albedos and snowalbedo feedback processes would be useful in the future.

Acknowledgements. This research was supported by Environment Canada, Natural Sciences and Engineering Research Council of Canada (NSERC), and joint EC/NSERC-funded "Network on Climate and Aerosols: Addressing Key Uncertainties in Remote Canadian Environments" (NETCARE). Funding for the development of the ECLIPSE emission data set was provided by the European Union Seventh Framework Programme (FP7/2007-2013) under grant agreement no. 282688 - ECLIPSE. Emission data sets are available from http://www.geiacenter.org/access (ECLIPSE), http://www.globalfiredata.org/data.html (GFED), and http:// tntcat.iiasa.ac.at: $8787 / \mathrm{RcpDb} / \mathrm{dsd}$ ?Action=htmlpage $\&$ page $=$ about (RCP). We would like to thank two anonymous referees and H.-W. Jacobi for their thoughtful comments on the manuscript and suggestions for improvements. In addition, we would like to thank Mark Flanner, Chris Fletcher, Chad Thackeray, Greg Flato, and Diana Verseghy for providing helpful comments on earlier versions of the manuscript. Furthermore, we would like to thank Sarah Doherty, who provided BC mixing ratio measurements, Florent Domine and Chris Derksen, who provided the measurements of the effective radius of snow, Mark Flanner, who provided lookup tables for parameterisations of dry snow aging, and Rashed Mahmood for helping to generate figures.

Edited by: H. Wang

\section{References}

Andrews, T., Gregory, J. M., Webb, M. J., and Taylor, K. E.: Forcing, feedbacks and climate sensitivity in CMIP5 coupled atmosphere-ocean climate models, Geophys. Res. Lett., 39, L09712, doi:10.1029/2012GL051607, 2012.

Aoki, T., Kuchiki, K., Niwano, M., Kodama, Y., Hosaka, M., and Tanaka, T.: Physically based snow albedo model for calculating broadband albedos and the solar heating profile in snowpack for general circulation models, J. Geophys. Res., 116, D11114, doi:10.1029/2010JD015507, 2011. 
Bartlett, P. A., Mackay, M. D., and Verseghy, D. L.: Modified snow algorithms in the Canadian Land Surface Scheme: model runs and sensitivity analysis at three boreal forest stands, AtmosphereOcean, 44, 207-222, 2006.

Bartlett, P. and Verseghy, D.: Modified treatment of intercepted snow improves the simulated forest albedo in the Canadian Land Surface Scheme, Hydrol. Processes, 29, 3208-3226, doi:10.1002/hyp.10431, 2015.

Bäumer, D., Lohmann, U., Lesins, G., Li, J., and Croft, B.: Parameterizing the optical properties of carbonaceous aerosols in the Canadian Centre for Climate Modeling and Analysis Atmospheric General Circulation Model with impacts on global radiation and energy fluxes, J. Geophys. Res.-Atmos., 112, D10207, doi:10.1029/2006JD007319, 2007.

Bond, T. C. and Bergstrom, R. W.: Light Absorption by Carbonaceous Particles: An Investigative Review, Aerosol Sci. Technol., 40, 27-67, 2006.

Bond, T. C., Bhardwaj, E., Dong, R., Jogani, R., Jung, S. K., Roden, C., Streets, D. G., and Trautmann, N. M.: Historical emissions of black and organic carbon aerosol from energy-related combustion, 1850-2000, Global Biogeochem. Cy., 21, Gb2018, doi:10.1029/2006gb002840, 2007.

Bond, T. C., Doherty, S. J., Fahey, D. W., Forster, P. M., Berntsen, T., DeAngelo, B. J., Flanner, M. G., Ghan, S., Kärcher, B., Koch, D., Kinne, S., Kondo, Y., Quinn, P. K., Sarofim, M. C., Schultz, M. G., Schulz, M., Venkataraman, C., Zhang, H., Zhang, S., Bellouin, N., Guttikunda, S. K., Hopke, P. K., Jacobson, M. Z., Kaiser, J. W., Klimont, Z., Lohmann, U., Schwarz, J. P., Shindell, D., Storelvmo, T., Warren, S. G., and Zender, C. S.: Bounding the role of black carbon in the climate system: A scientific assessment, J. Geophys. Res.-Atmos., 118, 5380-5552, doi:10.1002/jgrd.50171, 2013.

Brown, R. D. and Robinson, D. A.: Northern Hemisphere spring snow cover variability and change over 1922-2010 including an assessment of uncertainty, The Cryosphere, 5, 219-229, doi:10.5194/tc-5-219-2011, 2011.

Brown, R., Bartlett, P., Mackay, M., and Verseghy, D.: Estimation of snow cover in CLASS for SnowMIP, Atmosphere-Ocean, 44, 223-238, 2006.

Brun, E.: Investigation on wet-snow metamorphism in respect of liquid-water content, Ann. Glaciol., 13, 22-26, 1989.

Clarke, A. and Noone, K.: Soot in the Arctic: A cause for perturbation in radiative transfer, J. Geophys. Res., 19, 2045-2053, 1985.

Cole, J., Namazi, M., von Salzen, K., and Barker, H.: A new snow albedo parameterization for Canadian Land Surface Scheme (CLASS), in preparation, 2015.

Conway, H., Gades, A., and Raymond, C. F.: Albedo of dirty snow during conditions of melt, Water Resour. Res., 32, 1713-1718, doi:10.1029/96WR00712, 1996.

Croft, B., Lohmann, U., and von Salzen, K.: Black carbon ageing in the Canadian Centre for Climate modelling and analysis atmospheric general circulation model, Atmos. Chem. Phys., 5, 19311949, doi:10.5194/acp-5-1931-2005, 2005.

Derksen, C., Toose, P., Lemmetyinen, J., Pulliainen, J., Langlois, A., Rutter, N., and Fuller, M.: Evaluation of passive microwave brightness temperature simulations and snow water equivalent retrievals through a winter season, Remote Sens. Environ., 117, 236-248, 2012.
Déry, S. J. and Brown, R. D.: Recent Northern Hemisphere snow cover extent trends and implications for the snow-albedo-feedback, Geophys. Res. Lett., 34, L22504, doi:10.1029/2007GL031474, 2007.

Doherty, S. J., Warren, S. G., Grenfell, T. C., Clarke, A. D., and Brandt, R. E.: Light-absorbing impurities in Arctic snow, Atmos. Chem. Phys., 10, 11647-11680, doi:10.5194/acp-1011647-2010, 2010.

Doherty, S. J., Dang, C., Hegg, D. A., Zhang, R., and Warren S. G.: Black carbon and other light-absorbing particles in snow of central North America, J. Geophys. Res.-Atmos., 119, $12807-$ 12831, doi:10.1002/2014JD022350, 2014.

Domine, F., Albert, M., Huthwelker, T., Jacobi, H.-W., Kokhanovsky, A. A., Lehning, M., Picard, G., and Simpson, W. R.: Snow physics as relevant to snow photochemistry, Atmos. Chem. Phys., 8, 171-208, doi:10.5194/acp-8-171-2008, 2008.

Domine, F., Gallet J. C., Bock, J., and Morin, S.: Structure, specific surface area and thermal conductivity of the snowpack around Barrow, Alaska, J. Geophys. Res., 117, D00R14, doi:10.1029/2011JD016647, 2012.

Flanner, M. and Zender, C.: Linking snowpack microphysics and albedo evolution, J. Geophys. Res., 111, D12208, doi:10.1029/2005JD006834, 2006.

Flanner, M. G., Zender, C. S., Randerson, J. T., and Rasch, P. J.: Present-day climate forcing and response from black carbon in snow, J. Geophys. Res., 112, 202, doi:10.1029/2006JD008003, 2007.

Flanner, M. G., Zender, C. S., Hess, P. G., Mahowald, N. M., Painter, T. H., Ramanathan, V., and Rasch, P. J.: Springtime warming and reduced snow cover from carbonaceous particles, Atmos. Chem. Phys., 9, 2481-2497, doi:10.5194/acp-9-24812009, 2009.

Flanner, M. G., Liu, X., Zhou, C., Penner, J. E., and Jiao, C.: Enhanced solar energy absorption by internally-mixed black carbon in snow grains, Atmos. Chem. Phys., 12, 4699-4721, doi:10.5194/acp-12-4699-2012, 2012.

Fletcher, C. G., Thackeray, C. W., and Burgers, T. M.: Evaluating biases in simulated snow albedo feedback in two generations of climate models, J. Geophys. Res.-Atmos., 120, 12-26, doi:10.1002/2014JD022546, 2015.

Forsström, S., Ström, J., Pedersen, C. A., Isaksson, E., and Gerland, S.: Elemental carbon distribution in Svalbard snow, J. Geophys. Res., 114, D19112, doi:10.1029/2008jd011480, 2009.

France, J. L., King, M. D., Lee-Taylor, J., Beine, H. J., Ianniello, A., Domine, F., and MacArthur, A.: Calculations of in-snow $\mathrm{NO} 2$ and $\mathrm{OH}$ radical photochemical production and photolysis rates: A field and radiative-transfer study of the optical properties of Arctic (Ny-Ålesund, Svalbard) snow, J. Geophys. Res., 116, F04013, doi:10.1029/2011JF002019, 2011.

Gallet, J.-C., Domine, F., Arnaud, L., Picard, G., and Savarino, J.: Vertical profile of the specific surface area and density of the snow at Dome C and on a transect to Dumont D'Urville, Antarctica - albedo calculations and comparison to remote sensing products, The Cryosphere, 5, 631-649, doi:10.5194/tc-5-6312011, 2011.

Goldenson, N., Doherty, S. J., Bitz, C. M., Holland, M. M., Light, B., and Conley, A. J.: Arctic climate response to forcing from light-absorbing particles in snow and sea ice in CESM, Atmos. 
Chem. Phys., 12, 7903-7920, doi:10.5194/acp-12-7903-2012, 2012.

Grenfell, T. C. and Warren, S. G.: Representation of a nonspherical ice particle by a collection of independent spheres for scattering and absorption of radiation, J. Geophys. Res., 104, 3170937697, 1999.

Grenfell, T. C., Neshyba, S. P., and Warren, S. G.: Representation of a nonspherical ice particle by a collection of independent spheres for scattering and absorption of radiation: 3 . Hollow columns and plates, J. Geophys. Res., 110, D17203, doi:10.1029/2005JD005811, 2005.

Hadley, O. L. and Kirchstetter, T. W.: Black carbon reduction of snow albedo, Nature Clim. Change, 2, 437-440, 2012.

Hansen, J. and Nazarenko, L., Soot climate forcing via snow and ice albedos, Proc. Natl. Acad. Sci., 101, 423-428, 2004.

Hansen, J., Sato, M., Ruedy, R., Nazarenko, L., Lacis, A., Schmidt, G. A., Russell, G., Aleinov, I., Bauer, M., Bauer, S., Bell, N., Cairns, B., Canuto, V., Chandler, Cheng, Y., Genio, A. D., Faluvegi, G., Fleming, E., Friend, A., Hall, T., Jackman, C., Kelley, M., Kiang, N., Koch, D., Lean, J., Lerner, J., Lo, K., Menon, S., Miller, R., Minnis, P., Novakov, T., Oinas, V., Perlwitz, J., Perlwitz, J., Rind, D., Romanou, A., Shindell, D., Stone, P., Sun, S., Tausnev, N., Thresher, D., Wielicki, B., Wong, T., Yao, M., and Zhang, S.: Efficacy of climate forcings, J. Geophys. Res., 110, D18104, doi:10.1029/2005JD005776, 2005.

Hansen, J., Sato, M., Kharecha, P., Russell, G., Lea, D. W., and Siddall, M.: Climate change and trace gases, Philos. Trans. R. Soc. A, 365, 1925-1954, doi:10.1098/rsta.2007.2052, 2007a.

Hansen, J., Sato, M., Ruedy, R., Kharecha, P., Lacis, A., Miller, R., Nazarenko, L., Lo, K. Schmidt, G. A., Russell, G., Aleinov, I., Bauer, S., Baum, E., Cairns, B., Canuto, V. Chandler, M., Cheng, Y., Cohen, A., Del Genio, A., Faluvegi, G., Fleming, E., Friend, A., Hall, T., Jackman, C., Jonas, J., Kelley, M., Kiang, N. Y., Koch, D., Labow, G., Lerner, J., Menon, S., Novakov, T., Oinas, V., Perlwitz, Ja., Perlwitz, Ju., Rind, D., Romanou, A., Schmunk, R., Shindell, D., Stone, P., Sun, S., Streets, D., Tausnev, N., Thresher, D., Unger, N., Yao, M., and Zhang, S., Climate simulations for 1880-2003 with GISS modelE, Clim. Dynam., 29, 661-696, doi:10.1007/s00382-007-0255-8, $2007 \mathrm{~b}$.

Hedstrom, N. R. and Pomeroy, J. W.: Measurements and modelling of snow interception in the boreal forest, Hydrol. Process., 12, 1611-1625, 1998.

Holland, M. M., Bailey, D. A., and Briegleb, B. P.: Improved sea ice shortwave radiation physics in CCSM4: the impact of melt ponds and aerosols on Arctic sea ice, J. Climate, 25, 1413-1430, 2012.

Hurrell, J. W., Hack, J. J., Shea, D., Caron, J. M., and Rosinski, J.: A new sea surface temperature and sea ice boundary dataset for the community atmosphere model, J. Climate, 21, 5145-5153, 2008.

Jacobson, M. Z.: Climate response of fossil fuel and biofuel soot, accounting for soot's feedback to snow and sea ice albedo and emissivity, J. Geophys. Res., 109, D21201, doi:10.1029/2004JD004945, 2004.

Jiao, C., Flanner, M. G., Balkanski, Y., Bauer, S. E., Bellouin, N., Berntsen, T. K., Bian, H., Carslaw, K. S., Chin, M., De Luca, N., Diehl, T., Ghan, S. J., Iversen, T., Kirkevåg, A., Koch, D., Liu, X., Mann, G. W., Penner, J. E., Pitari, G., Schulz, M., Seland, Ø., Skeie, R. B., Steenrod, S. D., Stier, P., Takemura, T., Tsigaridis, K., van Noije, T., Yun, Y., and Zhang, K.: An AeroCom assess- ment of black carbon in Arctic snow and sea ice, Atmos. Chem. Phys., 14, 2399-2417, doi:10.5194/acp-14-2399-2014, 2014.

Keegan, K. M., Albert, M. R., McConnell, J. R., and Baker, I.: Climate change and forest fires synergistically drive widespread melt events of the Greenland ice sheet, Proc. Natl. Acad. Sci., 111, 7964-7967, doi:10.1073/pnas.1405397111, 2014.

Klimont, Z., Hoglund, L., Heyes, Ch., Rafaj, P., Schoepp, W., Cofala, J., Borken-Kleefeld, J., Purohit, P., Kupiainen, K., Winiwarter, W., Amann, M., Zhao, B., Wang, S. X., Bertok, I., and Sander, R.: Global scenarios of air pollutants and methane: 1990-2050, in preparation, 2015a.

Klimont, Z., Kupiainen, K., Heyes, Ch., Purohit, P., Cofala, J., Rafaj, P., Borken-Kleefeld, J., and Schoepp, W.: Global anthropogenic emissions of particulate matter, in preparation, 2015b.

Koch, D., Menon, S., Del Genio, A., Ruedy, R., Alienov, I., and Schmidt, G. A.: Distinguishing aerosol impacts on climate over the past century, J. Climate, 22, 2659-2677, doi:10.1175/2008jcli2573.1, 2009a.

Koch, D., Schulz, M., Kinne, S., McNaughton, C., Spackman, J. R., Balkanski, Y., Bauer, S., Berntsen, T., Bond, T. C., Boucher, O., Chin, M., Clarke, A., De Luca, N., Dentener, F., Diehl, T., Dubovik, O., Easter, R., Fahey, D. W., Feichter, J., Fillmore, D., Freitag, S., Ghan, S., Ginoux, P., Gong, S., Horowitz, L., Iversen, T., Kirkevåg, A., Klimont, Z., Kondo, Y., Krol, M., Liu, X., Miller, R., Montanaro, V., Moteki, N., Myhre, G., Penner, J. E., Perlwitz, J., Pitari, G., Reddy, S., Sahu, L., Sakamoto, H., Schuster, G., Schwarz, J. P., Seland, Ø., Stier, P., Takegawa, N., Takemura, T., Textor, C., van Aardenne, J. A., and Zhao, Y.: Evaluation of black carbon estimations in global aerosol models, Atmos. Chem. Phys., 9, 9001-9026, doi:10.5194/acp-9-9001-2009, 2009b.

Koch, D., Bauer, S., Del Genio, A., Faluvegi, G., McConnell, J. R., Menon, S., Miller, R. L., Rind, D., Ruedy, R., Schmidt, G. A., and Shindell, D.: Coupled aerosol-chemistry-climate twentieth century transient model investigation: Trends in shortlived species and climate responses, J. Climate, 24, 2693-2714, doi:10.1175/2011JCLI3582.1, 2011.

Kopacz, M., Mauzerall, D. L., Wang, J., Leibensperger, E. M., Henze, D. K., and Singh, K.: Origin and radiative forcing of black carbon transported to the Himalayas and Tibetan Plateau, Atmos. Chem. Phys., 11, 2837-2852, doi:10.5194/acp-11-28372011, 2011.

Lamarque, J.-F., Bond, T. C., Eyring, V., Granier, C., Heil, A., Klimont, Z., Lee, D., Liousse, C., Mieville, A., Owen, B., Schultz, M. G., Shindell, D., Smith, S. J., Stehfest, E., Van Aardenne, J., Cooper, O. R., Kainuma, M., Mahowald, N., McConnell, J. R., Naik, V., Riahi, K., and van Vuuren, D. P.: Historical (1850-2000) gridded anthropogenic and biomass burning emissions of reactive gases and aerosols: methodology and application, Atmos. Chem. Phys., 10, 7017-7039, doi:10.5194/acp10-7017-2010, 2010.

Lau, W. K. M., Kim, M. K., Kim, K. M., and Lee, W. S.: Enhanced surface warming and accelerated snow melt in the Himalayas and Tibetan Plateau induced by absorbing aerosols, Environ. Res. Lett., 5, 025204, doi:10.1088/1748-9326/5/2/025204, 2010.

Lee, Y. H., Lamarque, J.-F., Flanner, M. G., Jiao, C., Shindell, D. T., Berntsen, T., Bisiaux, M. M., Cao, J., Collins, W. J., Curran, M., Edwards, R., Faluvegi, G., Ghan, S., Horowitz, L. W., McConnell, J. R., Ming, J., Myhre, G., Nagashima, T., Naik, V., 
Rumbold, S. T., Skeie, R. B., Sudo, K., Takemura, T., Thevenon, F., Xu, B., and Yoon, J.-H.: Evaluation of preindustrial to presentday black carbon and its albedo forcing from Atmospheric Chemistry and Climate Model Intercomparison Project (ACCMIP), Atmos. Chem. Phys., 13, 2607-2634, doi:10.5194/acp13-2607-2013, 2013b.

Legagneux, L., Taillandier, A. S., and Domine, F.: Grain growth theories and the isothermal evolution of the specific surface area of snow, J. Appl. Phys., 95, 6175-6184, 2004.

Legrand, M., Preunkert, S., Schock, M., Cerqueira, M., KasperGiebl, A., Afonso, J., Pio, C., Gelencsér, A., and DombrowskiEtchevers I.: Major 20th century changes of carbonaceous aerosol components (EC, WinOC, DOC, HULIS, carboxylic acids, and cellulose) derived from Alpine ice cores, J. Geophys. Res., 112, D23S11, doi:10.1029/2006JD008080, 2007.

Lei, Y., Zhang, Q., He, K. B., and Streets, D. G.: Primary anthropogenic aerosol emission trends for China, 1990-2005, Atmos. Chem. Phys., 11, 931-954, doi:10.5194/acp-11-931-2011, 2011.

Lu, Z., Zhang, Q., and Streets, D. G.: Sulfur dioxide and primary carbonaceous aerosol emissions in China and India, 1996-2010, Atmos. Chem. Phys., 11, 9839-9864, doi:10.5194/acp-11-98392011, 2011.

Ma, X., von Salzen, K., and Li, J.: Modelling sea salt aerosol and its direct and indirect effects on climate, Atmos. Chem. Phys., 8, 1311-1327, doi:10.5194/acp-8-1311-2008, 2008.

McConnell, J. R. and Edwards, R.: Coal burning leaves toxic heavy metal legacy in the Arctic, Proc. Natl. Acad. Sci. USA 105, 12140-12144, doi:10.1073/pnas.0803564105, 2008.

McConnell, J. R., Edwards, R., Kok, G. L., Flanner, M. G., Zender, C. S., Saltzman, E. S., Banta, J. R., Pasteris, D. R., Carter, M. M., and Kahl, J. D. W.: 20th century industrial black carbon emissions altered Arctic climate forcing, Science, 317, 1381, doi:10.1126/science.1144856, 2007.

McConnell, J. R.: New Directions: Historical black carbon and other ice core aerosol records in the Arctic for GCM evaluation, Atmos. Environ., 44, 2665-2666, 2010.

Morin, S., Domine, F., Dufour, A., Lejeune, Y., Lesaffre, B., Willemet, J.-M., Carmagnola, C. M., and Jacobi, H. W.: Measurements and modeling of the vertical profile of specific surface area of an alpine snowpack, Adv. Water. Resour., 55, 111-120, doi:10.1016/j.advwatres.2012.01.010, 2013.

Moss, R. H., Edmonds, J. A., Hibbard, K. A., Manning, M. R., Ross, S. K., van Vuuren, D. P., Carter, T. R., Emori, S., Kainuma, M., Kram, T., Meehl, G. A., Mitchell, J. F. B., Nakicenovic, N., Riahi, K., Smith, S. J., Stouffer, R. J., Thomson, A. M., Weyant, J. P., and Wilbanks, T. J.: The next generation of scenarios for climate change research and assessment, Nature, 463, 747-756, 2010.

Murphy, D. M., Chow, J. C., Leibensperger, E. M., Malm, W. C., Pitchford, M., Schichtel, B. A., Watson, J. G., and White, W. H.: Decreases in elemental carbon and fine particle mass in the United States, Atmos. Chem. Phys., 11, 4679-4686, doi:10.5194/acp-11-4679-2011, 2011.

Oleson, K. W., Lawrence, D. M., Bonan, G. B., Flanner, M. G., Kluzek, E., Lawrence, P. J., Levis, S., Swenson, S. C., and Thornton, P. E.: Technical description of version 4.0 of the Community Land Model (CLM), Tech. Rep. NCAR/TN-478+STR, National Center for Atmospheric Research, Boulder, Colorado, USA, 2010.
Peng, Y., von Salzen, K., and Li, J.: Simulation of mineral dust aerosol with Piecewise Log-normal Approximation (PLA) in CanAM4-PAM, Atmos. Chem. Phys., 12, 6891-6914, doi:10.5194/acp-12-6891-2012, 2012.

Qu, X. and Hall, A.: What controls the strength of snow-albedo feedback?, J. Climate, 20, 3971-3981, doi:10.1175/JCLI4186.1, 2007.

Rypdal, K., Rive, N., Berntsen, T. K., Klimont, Z., Mideksa, T. K., Myhre, G., and Skeie, R. B.: Costs and global impacts of black carbon abatement strategies, Tellus B, 61, 625-641, doi:10.1111/j.1600-0889.2009.00430.X, 2009.

Shindell, D. T., Chin, M., Dentener, F., Doherty, R. M., Faluvegi, G., Fiore, A. M., Hess, P., Koch, D. M., MacKenzie, I. A., Sanderson, M. G., Schultz, M. G., Schulz, M., Stevenson, D. S., Teich, H., Textor, C., Wild, O., Bergmann, D. J., Bey, I., Bian, H., Cuvelier, C., Duncan, B. N., Folberth, G., Horowitz, L. W., Jonson, J., Kaminski, J. W., Marmer, E., Park, R., Pringle, K. J., Schroeder, S., Szopa, S., Takemura, T., Zeng, G., Keating, T. J., and Zuber, A.: A multi-model assessment of pollution transport to the Arctic, Atmos. Chem. Phys., 8, 5353-5372, doi:10.5194/acp-85353-2008, 2008.

Skeie, R. B., Berntsen, T., Myhre, G., Pedersen, C. A., Ström, J., Gerland, S., and Ogren, J. A.: Black carbon in the atmosphere and snow, from pre-industrial times until present, Atmos. Chem. Phys., 11, 6809-6836, doi:10.5194/acp-11-6809-2011, 2011.

Stamnes, K., Tsay, S.-C., Wiscombe, W., and Jayaweera, K.: Numerically stable algorithm for discrete-ordinate-method radiative transfer in multiple scattering and emitting layered media, Appl. Optics, 27, 2502-2509, 1988.

Stohl, A., Andrews, E., Burkhart, J. F., Forster, C., Herber, A., Hoch, S. W., Kowal, D., Lunder, C., Mefford, T., Ogren, J. A., Sharma, S., Spichtinger, N., Stebel, K., Stone, R., Ström, J., Tørseth, Wehrli, C., and Yttri, K. E.: Pan-Arctic enhancements of light absorbing aerosol concentrations due to North American boreal forest fires during summer 2004, J. Geophys. Res., 111, D22214, doi:10.1029/2006JD007216, 2006.

Stohl, A., Aamaas, B., Amann, M., Baker, L. H., Bellouin, N., Berntsen, T. K., Boucher, O., Cherian, R., Collins, W., Daskalakis, N., Dusinska, M., Eckhardt, S., Fuglestvedt, J. S., Harju, M., Heyes, C., Hodnebrog, Ø., Hao, J., Im, U., Kanakidou, M., Klimont, Z., Kupiainen, K., Law, K. S., Lund, M. T., Maas, R., MacIntosh, C. R., Myhre, G., Myriokefalitakis, S., Olivié, D., Quaas, J., Quennehen, B., Raut, J.-C., Rumbold, S. T., Samset, B. H., Schulz, M., Seland, Ø., Shine, K. P., Skeie, R. B., Wang, S., Yttri, K. E., and Zhu, T.: Evaluating the climate and air quality impacts of short-lived pollutants, Atmos. Chem. Phys., 15, 10529-10566, doi:10.5194/acp-15-10529-2015, 2015.

Sturm, M., Holmgren, J., König, M., and Morris, K.: The thermal conductivity of seasonal snow, J. Glaciol. 43, 26-41, 1997.

Tabler, R. D., Benson, C. S., Santana, B. W., and Ganguly, P.: Estimating snow transport from wind speed records: estimates versus measurements at Prudhoe Bay, Alaska, in: Proc. 58th Western Snow Conf., 17-19 April 1990, Sacramento, CA., pp. 61-78, 1990.

Taillandier, A.-S., Domine, F., Simpson, W. R., Sturm, M., Douglas, T. A., and Severin, K.: Evolution of the snow area index of the subarctic snowpack in Central Alaska over a whole season. Consequences for the air to snow transfer of pollutants, Environ. Sci. Technol., 40, 7521-7527, 2006. 
Taylor, K. E., Stouffer, R. J., and Meehl, G. A.: A summary of the CMIP5 experiment design. CMIP5 internal document, 2011.

van der Werf, G. R., Randerson, J. T., Giglio, L., Collatz, G. J., Mu, M., Kasibhatla, P. S., Morton, D. C., DeFries, R. S., Jin, Y., and van Leeuwen, T. T.: Global fire emissions and the contribution of deforestation, savanna, forest, agricultural, and peat fires (19972009), Atmos. Chem. Phys., 10, 11707-11735, doi:10.5194/acp10-11707-2010, 2010.

Verseghy, D.: The Canadian Land Surface Scheme CLASS (3.6), Technical Documentation, Tech. rep., Science and Technology Branch, Environment Canada, 2012.

von Salzen, K.: Piecewise log-normal approximation of size distributions for aerosol modelling, Atmos. Chem. Phys., 6, 13511372, doi:10.5194/acp-6-1351-2006, 2006.

von Salzen, K., Scinocca, J. F., McFarlane, N. A., Li, J., Cole, J. N. S., Plummer, D., Verseghy, D., Reader, M. C., Ma, X., Lazare, M., and Solheim, L.: The Canadian Fourth Generation Atmospheric Global Climate Model (CanAM4). Part I: Representation of Physical Processes, Atmos.-Ocean, 51, 104-125, doi:10.1080/07055900.2012.755610, 2013.
Wang, X., Doherty, S. J., and Huang J.: Black carbon and other light-absorbing impurities in snow across Northern China, J. Geophys. Res.-Atmos., 118, 1471-1492, doi:10.1029/2012JD018291, 2013.

Wang, Z. L., Zhang, H., and Shen, X. S.: Radiative forcing and climate response due to black carbon in snow and ice, Adv. Atmos. Sci., 28, 1336-1344, doi:10.1007/s00376-011-0117-5, 2011.

Warren, S. and Wiscombe, W.: A model for the spectral albedo of snow. II: Snow containing atmospheric aerosols, J. Atmos. Sci., 37, 2734-2745, 1980.

Warren, S. G. and Wiscombe, W. J.: Dirty snow after nuclear-war, Nature, 313, 467-470, 1985.

Wiscombe, W. J. and Warren, S. G.: A model for the spectral albedo of snow. I: Pure snow, J. Atmos. Sci., 37, 2712-2733, 1980.

Xu, B., Yao, T., Liu, X., and Wang, N.: Elemental and organic carbon measurements with a two-step heating gas chromatography system in snow samples from the Tibetan Plateau, Ann. Glaciol., 43, 257-262, doi:10.3189/172756406781812122, 2006. 